\title{
Ekonomik Özgürlüğün Girişimcilik Boyutunu Etkilemesine Yönelik Yapısal Eşitlik Modeli Uygulamasi

\author{
(The Implementation of Structural Equation Model for Economic Freedom to Affect the \\ Entrepreneurship Dimension)
}

\author{
Furkan Fahri ALTINTAŞ iD a \\ a Jandarma Genel Komutanlığı, Mersin, Türkiye. furkanfahrialtintas@gmail.com
}

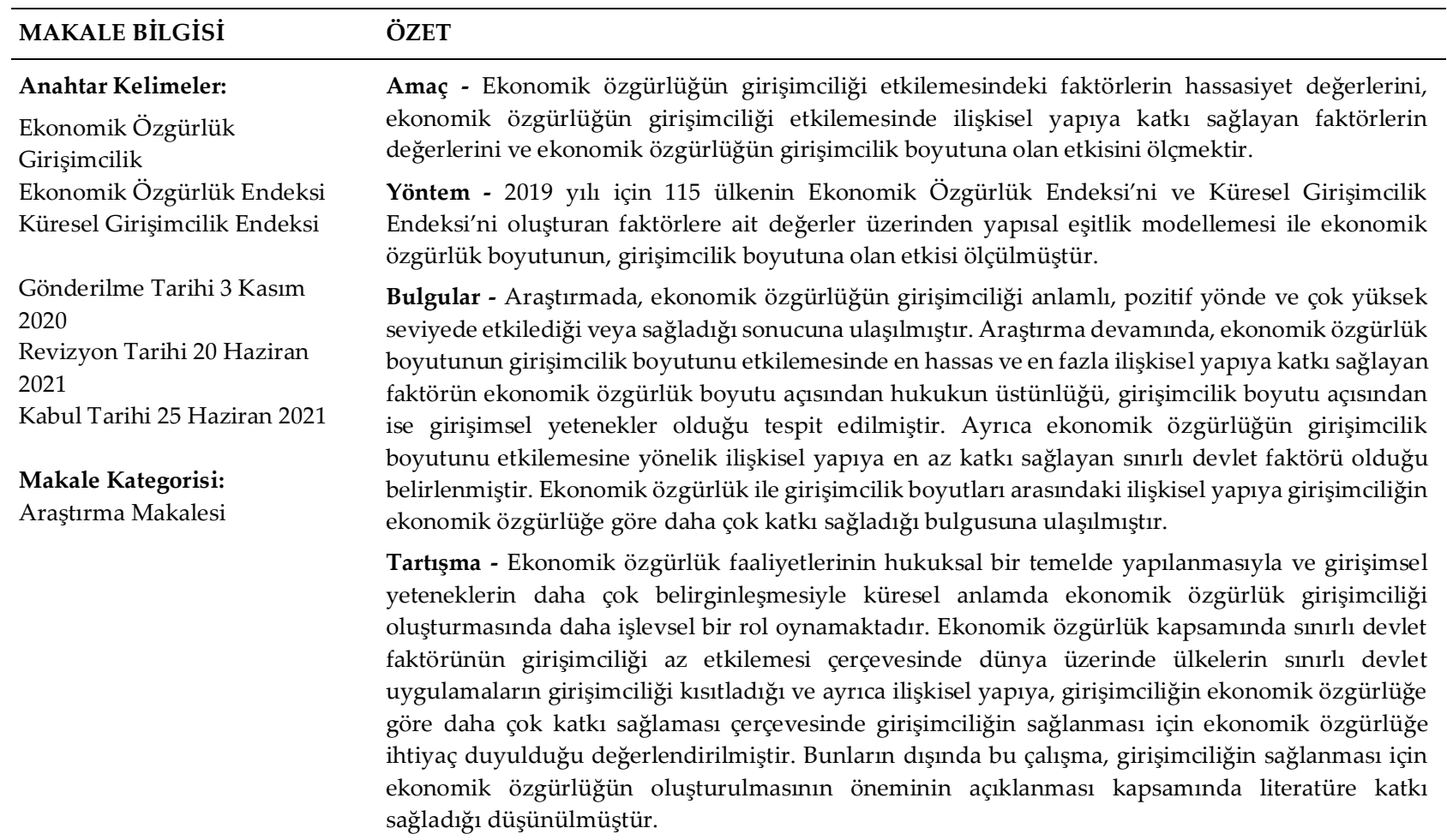

ARTICLE INFO

Keywords:

Economic Freedom

Entrepreneurship

Economic Freedom Index

Global Entrepreneurship Index

Received 3 November 2020

Revised 20 June 2021

Accepted 25 June 2021

Article Classification:

Research Article

\section{ABSTRACT}

Purpose - It is to measure the sensitivity values of the factors affecting the economic freedom's entrepreneurship, the values of the factors contributing to the relational structure in the effect of economic freedom on entrepreneurship and the effect of economic freedom on the entrepreneurship dimension.

Design/methodology/approach - For 2019, the effect of the economic freedom dimension on the entrepreneurship dimension was measured by structural equation modeling based on the values of the factors that constitute the Economic Freedom Index and the Global Entrepreneurship Index for 115 countries.

Findings - In the research, it was concluded that economic freedom affects or provides entrepreneurship in a significant, positive and very high level. In the continuation of the research, it was determined that the most sensitive and most contributing factor to the relational structure of the economic freedom dimension is the rule of law in terms of economic freedom and entrepreneurial skills in terms of entrepreneurship dimension. In addition, it has been determined that the goverment size factor contributes the least to the relational structure towards the effect of economic freedom on the entrepreneurship dimension. It has been found that entrepreneurship contributes more to the relational structure between economic freedom and entrepreneurship dimensions than economic freedom.

\section{Önerilen Atıf/ Suggested Citation}

Altıntaş, F.F. (2021). Ekonomik Özgürlüğün Girişimcilik Boyutunu Etkilemesine Yönelik Yapısal Eşitlik Modeli Uygulaması, İşletme Araştırmaları Dergisi, 13 (2), 1835-1855. 
Discussion - With the structuring of economic freedom activities on a legal basis and the more pronounced entrepreneurial capabilities, economic freedom plays a more functional role in the formation of entrepreneurship in the global sense. In the framework of the limited state factor affecting entrepreneurship less within the scope of economic freedom, it has been evaluated that goverment size practices of countries around the world restrict entrepreneurship and also, economic freedom is needed to ensure entrepreneurship within the framework of the relational structure, entrepreneurship contributes more than economic freedom. Apart from these, this study is thought to contribute to the literature in the context of explaining the importance of establishing economic freedom in order to ensure entrepreneurship.

\section{Giriş}

Ekonomik özgürlük, bireylerin ekonomik anlamda girişimlerinde hiçbir etki, baskı ve kısıtlama altında olmaksızın sağlanmasıdır. Ayın zamanda ekonomik özgürlük, bireylerin var olan mülkiyet haklarının korunması ve söz konusu mülkiyet haklarının devlet tarafından güvence altına alınmasını belirtmektedir. Bunun yanında ekonomik özgürlük, girişimsel anlamda bireylerin mal mübadelelerinde, bireysel tercihlerinde, pazarlardaki ve piyasalardaki faaliyetlerinde, üretimlerinde ve tüketimlerinde hiçbir baskı, etki ve zorlama altında olmadan özgürce ve gönüllülük esasına dayanılarak ekonomik faaliyetlerinin veya girişimciliği sağlanmasını açıklamaktadır (Miller, Kim ve Roberts, 2020).

Girişimcilik ise üretim faktörlerini bütünleştiren, değişim, yenileştirme, çeşitlendirme ve farklılaştırma ile risk alma ve belirsizlik koşulları altında katma değer ve olumlu getiri sağlama faaliyetleri olarak tanımlanmaktadır (Drucker, 1993). Dolayısıyla girişimcilik faaliyetleri için ekonomik özgürlüklere gereksinim duyulmakta olup, girişimcilik ekonomik özgürlüğün bir parçası halini almıştır. Bu nedenle ekonomik özgürlük, girişimcilik faaliyetlerinin nasıl teşvik edilebileceğinin yöntemini göstermektedir. Buna bağlı olarak ekonomik özgürlük girişimciliğin sağlanmasına etki etmekte olup, ülkelerin girişimcilik için ekonomik özgürlüğü sağlayacak imkânlar ve koşullar oluşturması büyük önem taşımaktadır (Falck ve Gäbler, 2016: 29).

Ekonomik özgürlüğün girişimciliği etkilemesinin çok işlevsel bir yapısı bulunmaktadır. Bu kapsamda ekonomik özgürlüğün girişimciliği sağlamasıyla, ülkelerde ekonomik gelişme, ekonomik kalkınma, ekonomik büyüme oluşabilecek, ülkelerin inovasyon, lojistik ve rekabet performansları artabilecek, toplumların refah, insani gelişme, yaşam kalitesi ile yaşam standart seviyeleri ile diğer sosyal ve teknik alanların iyileşmesi gerçekleştirebilecektir. Buna bağlı olarak ülkeler, kendilerinin ve birbirlerinin ekonomik özgürlük ile girişimcilik performanslarını takip etmektedirler. Çünkü ülkeler, ekonomik özgürlükler ile girişimciliği sağlayan bileşenlerin veya değişkenlerin ekonomik özgürlük ile girişimciliğin sağlamadaki yetersizliği daha spesifik ve ayrıntılı olarak neden-sonuç ilişkisi içinde analiz etme imkânı bulabilecektir. Böylelikle ülkeler, ekonomik özgürlüğü ve girişimciliği sağlamadaki eksikliğin giderilmesine yönelik düzenlemeler, stratejiler, yöntemler ve yönetimler geliştirebilirler. Bunun yanında ülkeler, diğer ülkelerin ekonomik özgürlük ile girişimcilik performanslarını takip ederek ekonomik özgürlük ile girişimciliği anlamlı olarak sağlayabilen ülkeleri analiz ederek kendi ekonomik özgürlüklerinin girişimciliği sağlama konularındaki eksikliklerin giderilmesi ve ülkelerin mevcut ekonomik özgürlüklerin girişimcilik performansının geliştirmesine yönelik diğer ülkeler ile işbirlikleri ve ortaklıklar sağlayabilmektedirler. Bu durum ise küresel anlamda yatırımın, ticaretin, inovasyonun, lojistiğin, bilim ile teknoloji ile daha birçok ekonomi ile doğrudan ve dolaylı olarak ilişkisi bulunan diğer boyutların gelişmesini sağlayıp insanlık için müşterek faydalar sağlanabilmesine yol açabilecektir. Dolayısıyla ülkeler, uluslararası alanda geçerliliği olan ülkelerin ekonomik özgürlük ve girişimcilik performanslarını ölçen ölçütlere, metriklere veya endekslere ihtiyaç duymakta olup, ülkelerin bütünsel anlamda ekonomik özgürlüğün girişimciliği etkilemesine yönelik ekonomik özgürlük ve girişimcilik boyutlarına ait bileşenlerin performanslarının tespiti önem kazanmaktadır.

Ülkelerin ekonomik özgürlük performanslarını ölçen çeşitli ölçütler bulunmaktadır. Bunlardan dünya çapında en bilinenlerden ve araştırmalarda dikkate alınanlardan bir tanesi Heritage Vakfı tarafından hazırlanan Ekonomik Özgürlük Endeksi (EÖE) olarak belirtilen metriktir. Ülkelerin girişimcilik performanslarının ölçülmesinde yine uluslararası alanda araştırmalarda kullanılan Küresel Girişimcilik ve Kalkınma Kurumu (GEDI) isimli kurum tarafından oluşturulan Küresel Girişimcilik Endeksi (KGE) olarak adlandırılan ölçüttür. Bu çalışmada da ekonomik özgürlüğün, girişimciliğin ve ekonomik özgürlüğün girişimciliği sağlamasının ülkeler için önemi çerçevesinde küresel değerler kapsamında ekonomik özgürlügün girişimciliğe olan etkisi belirlenmeye çalışılmıştır. 


\section{Kavramsal Çerçeve}

Ekonomik özgürlük, bireylerin serbestçe ekonomik faaliyetlerde bulunabilmesi ile bireylerin kendilerine ait kaynaklarda istediği zamanda tasarrufta bulunabilmesi hakkına sahip olmasıdır (Acar, 2010: 2; Miller, Kim ve Roberts, 2020). Buna göre ekonomik özgürlük kapsamında bireylerin müşterek tercihlerinden ziyade kişisel tercihler değerlendirilir. Ayrıca ekonomik özgürlük, devlet girişimiyle oluşan değişimden daha çok pazarlar veya piyasalar tarafından koordineli olarak gönüllü değişimin mevcutluğunu, yeni piyasalara girişinde, çıkışında ve piyasa içindeki rekabette özgürlüğün sağlanması ile dış etkenlerin kısıtlamalarını ve mülkiyet haklarının sağlanmasını açıklamaktadır. (Gwartney, Block ve Lawson, 1992; Gwartney ve Lawson, 2003; Beach ve Miles, 2005; Beach ve Kane, 2008; Miller ve Kim, 2013).

Hayek (1960), ekonomik özgürlüklerin sağlanmasında söz konusu özgürlüğün devlet tarafından teminatının olması gerektiğini vurgulamaktadır. Bu kapsamda Hayek (1960), ekonomik özgürlük için sağlanan güvencenin herkes için geçerli olması gerektiğini ve sağlanan güvence kapsamında hukuksal düzeni bozanların cezalandırılması gerektiğini belirtmektedir. Dolayısıyla bireylerin ekonomik faaliyetlerinin herhangi bir baskı altında kalmaksızın devlet tarafından güvence altına alınması, ekonomik özgürlügün sağlanması için büyük önem kazanmaktadır.

Ekonomik özgürlük, devletin ekonomik özgürlüğü sağlayabilecek uygun müdahalelerini belirtmektedir (Kantar, 2019: 4). Çünkü ekonomik özgürlük devlet müdahalelerin kısıtlanmasının yanında, uluslararası ticarette, serbest piyasada, rekabet edebilme serbestliği ve mülkiyet haklarının korunması anlamında yeni bir faaliyet alanı geliştirmiştir (Gwartney ve Lawson, 2003). Buna bağlı olarak ekonomik özgürlük, bireysel seçimlerdeki özgürlükler ile tamamen isteğe bağlı değişimleri içermektedir (Öztürk Çetenak ve Işık, 2016: 2).

Ekonomik özgürlüğün önemi, Adam Smith'in 1776 yılında yayımladığ 1 “Ulusların Zenginliği” isimli eserinde neden bazı ülkelerin zengin, buna karşın neden bazı ülkelerin fakir olması yönünde temel soru analiz edildiğinde daha çok belirgin hale gelmiştir (Faria ve Montesinos, 2009: 103). Çünkü Adam Smith eserinde, ülkelerin zenginliklerinin ve toplumların refahlarının sağlanmasında basit doğal özgürlük sisteminin önceliğini ve önemini vurgulamıştır. Teoride, ekonomik özgürlüğü zedeleyici faaliyetleri azaltmanın ekonomik büyümeyi, kalkınmayı ve gelişmeyi sağlayacak bir işlevselliği olduğu belirtilmektedir (Caudill, Zanella ve Mixon, 2000: 17; Stansel, 2012: 2).

Bir ülkede ekonomik özgürlügün gelişmesi için kişisel seçimlerin, gönüllü değişimlerin, bireylerin emek ile ürün piyasalarına girme fırsatlarının ve rekabetin geliştirilmesi gerekmektedir. Dolayısıyla bireylerin mesleklere ve ticari faaliyetlere girişini sınırlayan kısıtlamalar ekonomik özgürlüğü geciktirmektedir (Potrafke, 2013: 6). Böylelikle ekonomik özgürlük, bireyleri güçlendirmekte ve buna bağlı olarak ekonomik özgürlük, bireylerin ekonomik amaçlarına ulaşmasında ve ulaştığı amaçlardan yararlanmasında bir araç niteliği kazanmaktadır (Miller, Kim ve Holmes, 2014).

Ekonomik özgürlük ile ülkeler birbirlerine yatırım yapma ve ticari faaliyetlerde bulunma ortamını oluşturmaktadır. Böylelikle ülkelerin ekonomik özgürlük ile diğer ülkelere yatırım ve ticaret alanında sağladığı kolaylıklar daha çok pekişmektedir (Holmes ve Spalding, 2011). Ülkeler ekonomik anlamda ekonomik özgürlük ile kendi bünyesindeki sermaye akışlarını ve yatırım düzeylerini artırabilmektedirler. Dolayısıyla ülkelerin kendilerinin ve birbirlerinin ekonomik özgürlük performanslarını takip etmektedirler. Çünkü ülkeler ve diğer küresel ticari organizasyonlar yatırımlarını diğer ülkelerin ekonomik özgürlük performanslarına göre belirleyebilmektedirler. Böylelikle bu durum, yatırım yapılan ve sermaye girişi sağlanan ülke için ekonomisinin gelişmesine, kalınmasına ve istihdam düzeyinin artmasına neden olabilecektir. Yatırımı oluşturan ülke açısından ise diğer ülkelerin sağlamış olduğu ekonomik özgürlük ile kendi maliyetlerini düşürebilmekte, kar marjlarını yükseltebilmekte ve küresel anlamda rekabete katlanma seviyelerini artırabilmekte veya rekabet üstünlüklerini sağlayabilmektedir. Dolayısıyla ekonomik özgürlük ile ülkeler arasında artan ticari ve ekonomik ilişkiler neticesinde, küresel anlamda inovasyon, girişimcilik ARGE, patent çalışmaları ve lojistik hizmetleri konusunda uzmanlaşılarak tüm dünya vatandaşları için fayda oluşturulabilmektedir. Ekonomik özgürlük sadece ülkelerin ekonomik olarak değil, ekonomik özgürlügün dolaylı olarak çok işlevselliği açısından bilimin, tekniğin, sporun, sağlığın ve sosyal konuların gelişmeleri ile toplumların yaşam kalitelerinin, insani gelişmişlik seviyelerinin, refah düzeylerinin ve yaşam standartlarının artmasını sağlayabilmektedir. Dolayısıyla bütün bunlara bağlı olarak ülkelerin ekonomik özgürlük performanslarının ölçülmesi için her zaman metriklere, ölçütlere veya endekslere gereksinim duyulmaktadır. 
Ülkelerin ekonomik özgürlük açısından kendi performanslarının ne durumda olduğunu bilmesi ve kendi içinde ekonomik analiz yapabilmesi açısından ekonomik özgürlüğün ölçülmesi çok büyük önem arz etmiştir. Dolayısıyla ekonomik özgürlüğün ölçülmesinin önemi çerçevesinde ülkelerin ekonomik özgürlük performanslarının tespiti için çeşitli endeksler geliştirilmiştir (Kaya ve Çalışkan, 2016: 85).

Ülkelerin ekonomik özgürlük performanslarını tespit eden ölçütler veya metrikler ile ülkelerin ekonomik ve refah durumları arasındaki ilişki ülkelere göre kıyaslanabilmektedir. Bu kapsamda ilgili endekslere göre ülkelerin ekonomik özgürlüklerinin fazla olması, genel anlamda ülkelerin mülkiyet haklarının korunmasını, serbest ticareti, sınırlı devleti, düşük vergi oranını ve kişi başı gayri safi milli hasıla ile genel yaşam koşulları performanslarını anlamlı şekilde sağladıklarını göstermektedir (Campbell ve Rogers, 2007: 23). Böylelikle ülkelerin ekonomik performanslarını ölçen endeksler aracılı̆̆ı ile ekonomik fırsatlar ile refah arasındaki ilişki, her ülkenin kendisine özgü ekonomik politikaları değerlendirilerek tespiti yapılabilmektedir (Şahin, 2016).

Ülkelerin ekonomik özgürlüklerinin ölçülmesinde konusunda “Dünya Ekonomik Özgürlük Endeksi (DEÖE)”, “Freedom House Endeksi (FHE)" ve "Ekonomik Özgürlük Endeksi (EÖE)” olarak belirtilen endekslerden yararlanılarak söz konusu endeksler kapsamında ülkelerin ekonomik özgürlük performansları karşılaştırmalı olarak değerlendirilebilmektedir (Kešeljevic, 2007).

DEÖE, ilk olarak 1970 yılında Fraser Enstitüsü tarafından yayınlanmıştır. Endeks, 5 faktör ve 5 faktöre bağlı 24 adet bileşenden oluşmaktadır. Endekste faktörler; "kamu hacmi", "yasal yapı" ve "mülkiyet haklarının korunması", "para politikası ve fiyat istikrarı", "uluslararası ticari özgürlük ve düzenlemeler" olarak belirtilmiştir. Faktörlerin ve bileşenlerin derecelendirilmesi “ 0 " ile " 10 " değeri arasındadır. " 0 " en küçük ekonomik özgürlük değerini, "10" ise en büyük özgürlük değerini göstermektedir. Ayrıca söz konusu endeks kapsamında ülkelere ait ekonomik özgürlük verileri; “Uluslararası Para Fonu (IMF)”, "Dünya Bankası" ve “Dünya Ekonomik Formu” tarafından sağlanmaktadır (Altman, 2008; Fraser Institude, 2017).

FHE, ülkelerin siyasal haklar ve sivil özgürlükler performanslarını tespit eden ve Freedom House isimli kuruluş tarafından oluşturulan bir metriktir. Endeks ile ilk olarak 1973 yllında ülkelerin siyasal haklar ve sivil özgürlükler performansları ölçülmüştür. Endeks kapsamında ülkelerin siyasal haklarının değerlendirilmesi “ 0 " dan " 40 " a kadar, sivil özgürlüklerin değerlendirilmesi ise " 0 " dan " 60 " a kadar tasniflenmişlerdir (Freedom House, 2020). Ayrıca FHE ile ülkelerin ekonomik özgürlükleri doğrudan değil, dolaylı olarak ölçülebilmektedir. Çünkü ülkelerin ekonomik özgürlükleri, endeks kapsamında belirtilen siyasal haklar ve sivil özgürlükler performanslarının bir bileşeni olmasından dolayı ülkelerin ekonomik özgürlük performansları, ülkelerin siyasal haklar ve sivil özgürlükler performansları kapsamında değerlendirme yapılabilmektedir (Sucu, 2017). Araştırmalarda ülkelerin ekonomik özgürlük performanslarının tespit edilmesinde EÖE verilerinden sık olarak faydalanılmaktadır (Akıncı, Erkal ve Yılmaz, 2015: 149). EÖE ise Heritage Vakfı ve Wall Street Journal tarafından oluşturulmuştur. Söz konusu endeks ile ülkelerin ekonomik özgürlük performansları ilk olarak 1995 yılında tespit edilmiş olup, 2020 yılı itibari ile 186 ülke ekonomisini kapsamaktadır. Ayrıca endeks, dört faktör ve bu dört faktöre ait 12 bileşenden oluşmaktadır (Miller, Kim ve Roberts, 2020). Bu kapsamda EÖE'ni oluşturan faktörler ve faktörlere ait değişkenlerin açıklamaları Tablo 1'de sunulmuştur.

Tablo 1. EÖE Faktörleri ve Faktörlerin Bileşenleri

\begin{tabular}{|l|l|l|l|}
\hline Faktörler & Bileşenler & \\
\hline Hukukun Üstünlüğü & Mülkiyet Hakları & Devlet Bütünlüğü & Yargı Etkisi \\
\hline Sınırlı Devlet & Vergi Yükü & Kamu Harcamaları & Mali Sağlamlık \\
\hline Bürokrasi Etkinliği & İş Özgürlüğü & İsücü Özgürlüğ̈̈ & Parasal Özgürlük \\
\hline Serbest Piyasa & Ticaret Özgürlüğg̈u & Yatırım Özgürlüğg̈ & Finansal Özgürlük \\
\hline
\end{tabular}

Kaynak: Heritage Foundation, 2020

Tablo 1'de belirtilen dört faktöre ait 12 ekonomik özgürlük bileşeninin her biri “ 0 " ile " 100 ” puan arasındadır. Buna bağlı olarak bileşenlerin aritmetik ortalamaları hesaplanması ile faktörler, faktörlerin aritmetik ortalamaları hesaplanmasıyla ülkelerin ekonomik performansları belirlenmektedir (Heritage Foundation, 2020). Bunun yanında endeks, bireylerin emeğinin, sermayesinin ve diğer faktörlerin ülkeler kapsamındaki özgürlük seviyelerini açıklamaktadır. Buna göre, dünyanın en gelişmiş ülkeleri aynı zamanda ekonomik özgürlük seviyesi en fazla olan ülkeler olarak değerlendirilebilir (Dam ve Şanlı, 2019). 


\section{F. F. Altıntaş 13/2 (2021) 1835-1855}

Ülkelerin ekonomik özgürlük performanslarını tespit eden endeksler kıyaslandığında, EÖE diğer endekslere göre daha güncel derlemeyle hazırlanmıştır. Ayrıca EÖE ve DEÖE ülkelerin ekonomik özgürlüklerini doğrudan, buna karşın FHE ise dolaylı olarak ölçmektedir. Dolayısıyla ülkelerin ekonomik özgürlükleri performanslarının değerlendirilmesinde EÖE ve DEÖE kapsamında daha yalın sonuçlara ulaşılabilecektir.

Girişimcilik kavramı ilk olarak 18.yy başlarında Cantillon tarafından açılanmış olup, girişimcilik netleşmemiş bir fiyat ile satmak için üretim girdilerini ve hizmetlerini önceden satın alan ve buna göre katma değer veya getiri sağlayan faaliyetler olarak belirtilmiştir (Gerni vd, 2012: 762). Shumpeter (1934) ise girişimciliği inovasyon kavramı ile bütünleşik olarak değerlendirmiştir. Schumpeter (1934) bu kapsamda girişimciliği, oluşturucu yıkım teorisine istinaden eski teknolojilerin ve üretim tekniklerinin yerine yeni olan teknoloji ve üretim teknikleri sağlanarak farklılaşma ve çeşitlenme açısından katma değer ve olumlu getiri sağlayan faaliyetler olarak açılanmıştır. Say (1971) ise girişimciliği, risk alma ve üretim faktörlerinin optimal şekilde kullanılması kapsamında çalışma faaliyeti gösterenlerden emeklerini, sermaye sahibinden ise varlık değerlerini kiralayarak ekonomik faaliyetlerin ve ilişkilerin temelini oluşturan kesimin yapmış olduğu katma değer faaliyetler bütünü olarak açıklamıştır. Günümüzde ise girişimcilik, genel anlamda üretim faktörlerini (emek, sermaye, doğa ve teknoloji) bütünsel anlamda bir arada toplayan, riskleri, yenilikleri ve fırsatları değerlendirebilen üretim faaliyeti faktörleri olarak değerlendirilebilir. Buna bağlı olarak girişimci ise iktisadi kaynakları düşük verimli yapıdan yüksek verimli yapıya dönüştürebilen aktördür. Dolayısıyla girişimci, atıl kaynakları etkin, etkili ve verimli hale dönüştürerek katma değer ve olumlu getiri sağlama faaliyeti içindedir (Pehlivanoğlu ve Kayan, 2019: 59).

Genel anlamda girişimcilik; "Schumpeteryan girişimciler", "iç girişimciler" ve "yönetici-işletme sahibi" olmak üzere üç çeşidi bulunmaktadır. Schumpeteryan girişimciler, kendi nam ve hesabı için faaliyet yapan girişimciliği açıklamaktadır. İç girişimciler ise belirli bir bedel karşılığında girişimcilik faaliyetlerini oluşturanları belirtmektedir. Son olarak yönetici işletme sahibi, kendi nam ve hesabına çalışıp yönetici faaliyetlerinde girişimcilik sağlayanlar olarak ifade edilmiştir (Işık, Göktaş ve Kılınç, 2011). Bazı yazın alanında ise girişimcilik 5 boyutta değerlendirilmektedir. Bunlar; "kamu ekonomisi ve pazar ekonomisi kapsamında açıklanan mülkiyet boyutu açısından girişimcilik", "kurulan organizasyonların büyüklüğünü esas alan büyüklük açısından girişimcilik", "girişimcilik kavramının nasıl oluştuğunu belirten ve girişimciliğin gelişim sürecinde sahip olduğu nitelikleri ile girişimciliğin hangi türde olduğunu açıklayan girişimcilik", "açık pazarda oluşturulan ve tamamıyla kâr amaçlı gerçekleştirilen Chicken modeli girişimcilik" ve son olarak "bilişim teknolojileri ile faaliyetlerini sağlayan e-girişimciklik" olarak açıklanmaktadır (Ünüvar, 2019: 15-17). Başka bir yazın alanına göre girişimcilik; "yenilikçi", "fırsat", "yaratıcı", "çevreci", "içsel", "sosyal", "genç" ve "teknolojik" girişimcilik olarak tasniflenmiştir (Kaya, 2019: 20-24).

Girişimcilik, ülkelerin sosyal ve ekonomik olarak gelişmesinde önemli bir rol oynamaktadır Çünkü girişimcilik faaliyetleri ile yeni ticari organizasyonlar kurulabilmekte ve buna bağlı olarak istihdam oluşabilmektedir (Audretsch, 2003). Dolayısıyla girişimcilik faaliyetleri ile mutlak bir yatırım artışı sağlanarak ülkelerin ekonomilerinin büyümeleri sağlanabilmektedir (Drucker, 2002; Wennekers ve Thurik, 1999; Ács ve Armington, 2014; Wong vd, 2005).

Girişimciliğin önemi üç boyutta değerlendirilebilmektedir. Bunlar; “ekonomik anlamda girişimciliğin önemi", "sosyal açıdan girişimciliğin önemi" ve "girişimciliğin sahip olduğu nitelik açısından önemi" kapsamında açıklanabilir. Ekonomik anlamda girişimciliğin önemi, girişimciler tarafından tercih edilen malların ve hizmetlerin, girişimciler tarafından oluşturulan stratejiler ve yöntemler ile pazarlara sunulması olarak açıklanmaktadır. Dolayısıyla girişimcilik konusunda ideal stratejiler ve yöntemler sayesinde toplum ve ülke için fayda sağlanabilecektir. Sosyal açıdan girişimciliğin önemi kapsamında ise girişimci sayısının artması, toplumların refah düzeylerinin, yaşam kalitelerinin, yaşam standartlarının ve insani gelişmişlik seviyelerinin artmasına yol açmaktadır. Bunun yanında girişimcilik faaliyetleri kapsamında inovasyon ile birlikte bilimde ve teknolojide yenilikler sağlanabilmektedir. Son olarak girişimcilerin sahip olduğu nitelik açısından girişimcilik; girişimcilerin rekabetçi düşünmeleri, öncü olmaları, risk almaları, yenilikçi ve sorumluluk bilincinde olmaları ve sonraki girişimcilik faaliyetlerini geliştiren ve artıran bir işlevselliği olması çerçevesinde değerlendirilebilir (Şahin, 2016: 4-8).

Girişim boyutunun mikro anlamda organizasyonlara, makro anlamda ise ülkelerin ekonomik, teknik ve sosyal boyutlarını geliştirici bir etkisi bulunmaktadır. Bu kapsamda ülkeler girişimcilik faaliyetlerini geliştirmeye ve 
genişletmeye yönelik yöntemler, stratejiler, yönetimler ve uygulamalar sağlamaktadırlar. Buna bağlı olarak ülkelerin kendilerinin ve birbirlerinin girişimcilik performanslarının farkında olmaları ve takip etmeleri büyük önem kazanmaktadır. Çünkü ülkeler, kendi girişimcilik performanslarının farkında olarak girişimcilik konusunda eksik kalan hususlar hakkında ve mevcut potansiyelini geliştirici uygulamalar gerçekleştirebileceklerdir. Bunun yanında ülkeler, birbirlerinin girişimcilik performanslarını takip ederek girişimcilik performansı iyi olan ülkeler ile işbirlikleri ve ortaklıklar sağlayarak kendi girişimcilik potansiyellerini artırabilirler. Dolayısıyla ülkeler, her zaman kendilerinin ve diğer ülkelerin girişimcilik performanslarının farkında olması gerekliliği ve bilinci kapsamında ülkelerin girişimcilik performanslarını tespit eden ölçeklere, metriklere veya endekslere ihtiyaç duymaktadırlar.

Ülkelerin girişimcilik ile doğrudan ve dolaylı olarak çeşitli göstergelere ait veriler kullanılarak ülkelerin küresel anlamdaki girişimcilik seviyelerini ve girişimci örgütlerin başarılarını tespit etmek amacıyla ABD'nde GEDI isimli bir kurum oluşturulmuştur. Söz konusu kurumun ülkelerin girişimcilik performanslarını ölçmek için kullandığı metriklerden bir tanesi KGM, diğeri ise KGE'dir (Bosma ve Levie, 2010: 8, Kim vd, 2015; Şenturan ve Şentürk, 2016).

KGM, ilk olarak 1999 yılında belirli sayıda ülkelerin, sonraki yıllarda ise onlarca ülkenin girişimcilik performanslarının tespit edilmesi ile uluslararası bir nitelik kazanmıştır. Buna bağlı olarak KGM, uluslararası yayınlar ve yıllık raporlar ile ülkelerin mukayeseli olarak girişimcilik performanslarının tespit edilmesinde yararlanılan kaynaklardan biri halini almıştır (Bergmann, Müller ve Schrettle, 2013). Bunun yanında KGM; "girişimcilik hakkında kişisel algılar", "etkinlik endeksi", "motivasyon endeksi", "cinsiyet eşitliği", "girişimcilik etkisi", "girişimciliğe toplumsal bakış" ve "girişimsel yapı koşulları" olmak üzere toplam 7 bileşenden oluşmaktadır. Ayrıca KGM kapsamında söz konusu 7 bileşene ait 24 değişken bulunmaktadır (Bosma ve Kelley, 2019; Torun, 2019: 57).

KGE, 2008 yılında oluşturulmuş olup, söz konusu endeks temelini GEDI isimli kuruluşun verilerine dayanmaktadır (Karadağ, 2018). KGE üç faktör, faktörlere bağlı 14 bileşen ve 14 bileşeni oluşturan 14 kurumsal ve 14 bireysel değişkenden oluşmaktadır (Ács ve Szerb, 2019). Bu kapsamda KGE'ni oluşturan faktörler, bileşenler ve değişkenler Tablo 2'de gösterilmiştir.

Tablo 2. KGE Alt Dizinleri, Sütunları ve Değişkenleri

\begin{tabular}{|c|c|c|c|}
\hline Alt Dizinler (Faktörler) & Sütunlar (Bileşenler) & $\begin{array}{l}\text { Kurumsal } \\
\text { Değişkenler }\end{array}$ & Bireysel Değişkenler \\
\hline \multirow{5}{*}{$\begin{array}{l}\text { Girişimsel Tutumlar Alt } \\
\text { Dizini }\end{array}$} & Firsat Algisı & Pazar Yı̆̆ılması & Firsatları Tanıma \\
\hline & Beceri & Yüksek Öğrenim & Beceri Alg1s1 \\
\hline & Risk Alma & İş Riski & Risk Kabulü \\
\hline & A $\breve{g}$ Kurma & İnternet Kullanımı & Girişimcileri Tanıma \\
\hline & Kültürel Destek & Yolsuzluk & Kariyer Durumu \\
\hline \multirow{4}{*}{$\begin{array}{l}\text { Girişimsel Yetenekler Alt } \\
\text { Dizini }\end{array}$} & Fırsat Girişimi & Ekonomik Özgürlük & Firsat Motivasyonu \\
\hline & Teknoloji Emilimi & Teknoloji Eğilimi & Teknoloji Seviyesi \\
\hline & İnsan Kaynakları Kalitesi & Personel Eğitimi & Eğitim Seviyesi \\
\hline & Rekabet & Pazar Hakimiyeti & Rekabet Edenler \\
\hline \multirow{5}{*}{$\begin{array}{l}\text { Girişimsel Amaçlar Alt } \\
\text { Dizini }\end{array}$} & Ürün Yenilikçiliği & Teknoloji Transferi & Yeni Ürün \\
\hline & Süreç Yenilikçiliği & $\begin{array}{l}\text { AR-GE'nin } \\
\text { GSMH'larındaki } \\
\text { Oranı } \\
\end{array}$ & Yeni Teknolojiler \\
\hline & Yüksek Büyüme & İş Stratejisi & Ceylan \\
\hline & Uluslararasılaşma & Küreselleşme & İhracat \\
\hline & Risk Sermayesi & Girişim Sermayesi & Resmi Olmayan Yatırım \\
\hline
\end{tabular}

Kaynak: Ács vd, 2019

Tablo 2'de açıklanan girişimcilik faktörlerin, faktörleri oluşturan bileşenlerin ve son olarak bileşenleri oluşturan değişkenlerin her faktör, bileşen ve değişken kendi arasında birbirlerini tamamlayıcı bir özelliği bulunmaktadır. Dolayısıyla KGE'ni oluşturan faktörlerin, bileşenlerin ve değişkenlerin faktör, bileşen ve değişken bazında kendi arasında anlamlı, pozitif yönlü ilişkilerin olması beklenmektedir (Ács vd, 2019). 
KGE ve KGM karşılaştırıldığında, KGE KGM'ne göre daha ayrıntılı ve daha çok değişkene sahip olup, daha güncel olarak hazırlanmıştır. Buna karşın, KGM'nü oluşturan faktörlerin, bileşenlerin ve değişkenlerin birbirlerini tamamlaması kapsamında KGM, KGE'ne göre daha bütüncül bir özellik göstermektedir. Bunun yanında, ülkelerin girişimcilik performanslarının açıklanmasında KGE daha çok girişimciliğin teknik boyutunu, KGM ise girişimciliğin sosyal boyutunu açıklamıştır. Literatürde ise ülkelerin girişimcilik performansının ölçülmesinde her iki metrikten istifade edildiği tespit edilmiştir.

Girişimciliği sağlanmasında temel ve en önemli koşullardan bir tanesi ekonomik özgürlüğün sağlanması ve bu özgürlüğün korunarak devlet güvencesi altına alınmasıdır (Gilad ve Levine, 1986; Miles vd, 2006). Aynı zamanda ekonomik özgürlükler kapsamında serbest piyasanın varlığı, girişimciliği teşvikte en önemli ilkelerden biridir. Bu kapsamda fiyat kontrolleri, vergiler, ithalat ve ihracat tarifeleri ile parasal kontrol girişimcilik faaliyetlerin oluşmasında aracılar olarak kabul edilmektedir (Kirzner, 1992).

Girişimcilik faaliyetlerin gelişmesinde ekonomik özgürlük fonksiyonel bir yapı niteliğini kazanmaktadır. Özellikle girişimciliğin oluşmasında ekonomik özgürlük çerçevesinde dört temel oluşumun sağlanması gerekmektedir. Bunlar; "açık iş yapısına özgürlük (girişimciler için bürokrasi ve düzenleme maliyetlerinin düzenlenmesi)", "mali özgürlük (sermaye kazanc1, gelir ve kurumlar vergilerinin girişimciliğe yönelik denetimin sağlanması)”, "uluslararası ticaret özgürlüğü (uluslararası ticarete yönelik sınırlamaların ortadan kaldırılması ve piyasa katılım teşviklerinin artması ile girişimcilik faaliyetlerinin sağlanması)", "yatırım özgürlüğü (girişimciliğin finanse edilmesinde ve girişimciliğin oluşturulmasında verimli bir zemin hazırlanması)" olarak belirtilebilir (Echeverri, Haar ve Estévez-Bretón, 2013: 67).

Ekonomik özgürlük ile girişimcilik boyutları arasındaki ilişki kapsamında Sobel, Clark ve Lee (2007), ülkelerdeki ekonomik özgürlükler ne kadar çok olursa, ekonomik büyümenin ve buna bağlı olarak girişimciliğin o kadar fazla olabileceğini ifade etmişlerdir. Buna göre yazarlar, ekonomik büyümenin özellikle özel sektör gelişimindeki girişimciliği sağlamasında olumlu etkilerinin olduğunu belirtmişlerdir. Lee (1991) ise girişimciliğin temel anlamda gelişiminin bir ülkedeki uygun ekonomik yapılanma ile gerçekleşebileceğini düşünerek girişimciliğin temel yapısından gelişme sürecine kadar ekonomik özgürlüklerle beslenebileceğini vurgulamıştır. Williamson ve Mathers (2009), ekonomik özgürlük ile girişimcilik ilişkisine ekonomik özgürlüğün iki temel özelliği olan mülkiyet hakların korunması ile bireylerin ekonomik işlemlerinin özgür ve serbest iradesi ile sağlanabilmeleri açısından yaklaşmışlardır. Bu kapsamda yazarlar, ekonomik özgürlük ile desteklenen özel mülkiyetin ekonomideki işlemlerinin girişimcilikteki temel yapı olduğunu belirtmekte olup, ekonomik özgürlük ile desteklenen özel mülkiyetin ekonomideki işlemlerin girişimcilik faaliyetlerinin sürdürebilirliğine, gelişmesine ve girişimcilik faaliyetlerinin de inovasyona yol açacağını belirtmişlerdir. Ayrıca Kutbay (2020), ekonomik özgürlük kapsamında mülkiyet hakları özgürlügünün girişimcilik faaliyetlerini sağlayacağı için bu durum vergi mükelleflerinin sayısını artırıp ülke ekonomisine katkıda bulunabileceğini açıklamıştır.

Girişimcilerin başarısı, devlet tarafından oluşturulmuş adaletli ve iyileştirilmiş kurumsal oluşumlara ve temel ekonomik özgürlüklerin sağlanmış olmasına bağlıdır (Akın, 2020). Bu kapsamda girişimciliğin gelişmesi için iki temel koşul oluşmaktadır. Bunlardan birincisi, ekonomik özgürlüklerin sağladığı koşullar altında ekonomik bir girişim kurma özgürlüğü ve girişimcilik faaliyetlerinde yaratıcı ve yenilikçi olma özgürlügüdür. İkincisi ise ekonomik özgürlüklerin sağlanarak ülkelerin ve organizasyonların ekonomik anlamda katma değer ve getiri sağlayacak girişimcilik fırsatları sağlayan elverişli ekonomik koşulların sağlanmasıdır (Dollinger, 2008: 12).

Ekonomik özgürlüğün en uygun biçimi; mutlak bir mülkiyet hakkı sağlamak, emek-sermaye, mallarhizmetler için tam anlamıyla gerçekleştirilmiş dolaşım özgürlüğü oluşturmak ve müdahalenin mutlak anlamda yokluğunu gerçekleştirmektir. Dolayısıyla ekonomik özgürlük sağlamanın temel amacı, girişimciliği teşvik ederek ve ekonomik fonksiyonlar ile iş ortamlarını liberalleştirerek girişimciliğin merkezden uzak bir yerel yapıya kavuşturmaktır (Hossain, 2016: 200). Bunun yanında, ekonomik özgürlük ile girişimciler için yeni fırsatlardan yararlanma özgürlüğ̈ sağlanarak yapısal özerkliğe sahip girişimcilerin girişimcilik faaliyetlerinin kaliteleşmesi sağlanabilmektedir (Batjargal, 2003). Çünkü bireysel girişimcilik, algılanan özgürlük derecelerini yansıtmaktadır. Böylelikle ekonomik özgürlük yapısına sahip olan girişimciler, hedeflerini optimize eden diziler arasında rasyonel anlamda seçim yapabilme olanağına sahip olurlar (Baumol, 1990; Valliere, 2008). 


\section{F. F. Altıntaş 13/2 (2021) 1835-1855}

Ülkeler genellikle girişimcilik faaliyetlerini teşvik etmek için ekonomik özgürlük pahasına piyasa sürecine devlet müdahalelerini içeren çok çeşitli politika programlarını izleyebilmektedirler. Bu tür müdahaleler, girişimciliğin gelişmesine kısa vadede çözüm olabilmektedir. Buna karşın söz konusu bu müdahaleler bireylerin uzun vadede yenilikçi girişimlerini engellediği ve bu durumun ise inovasyonun gelişim gösterememesine neden olabilmektedir (Bennett ve Nikolaev, 2019). Dolayısıyla sinırlı devlet kapsamında ekonomik özgürlüğün sağlanması, girişimcilerin kendi faaliyetlerini daha anlamlı olarak yapmalarına fırsat sağlamaktadır (Demsetz, 1982).

\section{Literatür}

Literatür incelendiğinde, ekonomik göstergeler ile girişimcilik göstergelerinin diğer boyutlar veya birbirleri ile olan ilişkilerinin tespitinde genellikle panel veri analizi kullanılmaktadır. Buna karşın, ekonomik ve girişimcilik boyutlarının göstergelerinin birbirleri veya diğer boyutlar ile olan ilişkilerinin tespitinde farklı istatistik tekniklerinden de istifade edilmiştir. Buna göre, söz konusu ekonomik ve girişimcilik konularını ele alan çalışmalarda kullanılan teknikler Tablo 3'de gösterilmiştir.

Tablo 3. Ekonomik ve Girişimcilik Göstergelerin Birbirleriyle ve Diğer Boyutlar ile Olan İlişkilerinde Kullanılan Yöntemler

\begin{tabular}{|c|c|c|}
\hline Araştırma/Araştırmacılar & Araştırma Konusu & İstatistik Yöntemi \\
\hline Gwartney, Lawson ve Holcombe (1999) & \begin{tabular}{|l|} 
Ekonomik Özgürlüğün Yıllık Kişi Başı GSMH \\
değişimi ile Olan İlişkisi
\end{tabular} & \begin{tabular}{|l|} 
Doğrusal \\
Regresyon \\
\end{tabular} \\
\hline Antoncic (2007) & $\begin{array}{l}\text { Çevre, Girişimcilik, Ekonomik Büyüme ve } \\
\text { Ekonomik Karlılık Arasındaki İlişki }\end{array}$ & \begin{tabular}{|l|} 
Yapısal Eşitlik \\
Modellemesi \\
\end{tabular} \\
\hline Bjørnskov ve Foss (2008) & $\begin{array}{l}\text { Ekonomik Özgürlük ile Girişimcilik } \\
\text { Arasındaki İlişki }\end{array}$ & \begin{tabular}{|l|} 
Doğrusal \\
Regresyon \\
\end{tabular} \\
\hline McMullen, Bagby ve Palich (2008) & $\begin{array}{l}\text { Ekonomik Özgürlük ile Firsat Motiveli ve } \\
\text { Gereksinim Motiveli Girişimcilik ile Olan } \\
\text { İlişkisi }\end{array}$ & $\begin{array}{l}\text { Pearson } \\
\text { Korelasyon }\end{array}$ \\
\hline Nystörn (2008) & $\begin{array}{l}\text { Ekonomik Özgürlük ile Girişimcilik } \\
\text { Arasındaki İlişki }\end{array}$ & $\begin{array}{l}\text { Doğrusal } \\
\text { Regresyon }\end{array}$ \\
\hline Stenholm, Acs ve Wuebker (2013) & $\begin{array}{l}\text { Ekonomik Özgürlüğün Girişimcilik Faaliyeti } \\
\text { ve Girişimcilik Oranına Olan Etkileri }\end{array}$ & $\begin{array}{l}\text { Yapısal Eşitlik } \\
\text { Modellemesi }\end{array}$ \\
\hline Prasetyo (2019) & $\begin{array}{l}\text { Girişimcilik Kültürünün, A } \breve{g} \text { yapıların ve } \\
\text { Rekabetin Ekonomik Büyümeye Olan Etkileri }\end{array}$ & $\begin{array}{l}\text { Yapısal Eşitlik } \\
\text { Modellemesi }\end{array}$ \\
\hline Şahinoğlu ve Yakut (2019) & $\begin{array}{l}\text { Ekonomik Özgürlük Endeksinin Ekonomik } \\
\text { Performans Boyutuna (GSYH, doğrudan } \\
\text { yabancı sermaye yatırımları, enflasyon, cari } \\
\text { işlemler açığı, işsizlik oranları, hükümet } \\
\text { borçları ve dışa açıklı oranı) Olan Etkileri }\end{array}$ & $\begin{array}{l}\text { Yapısal Eşitlik } \\
\text { Modellemesi }\end{array}$ \\
\hline Elverdi ve Atik (2020) & $\begin{array}{l}\text { Girişimciliğin (küresel girişimcilik monitörü) } \\
\text { Ekonomik Büyümeye (kişi başı GSYH) Olan } \\
\text { Etkisi }\end{array}$ & $\begin{array}{l}\text { Yapısal Eşitlik } \\
\text { Modellemesi }\end{array}$ \\
\hline
\end{tabular}

Ekonomik özgürlük ve girişimcilik boyutlarının diğer boyutlar ile olan ilişkileri çerçevesinde literatürde daha çok ekonomik özgürlük boyutunun ekonomik büyümeye, gelir düzeyine, ekonomik kalkınmaya ve ekonomik performansa, girişimcilik boyutunun ise inovasyona, örgütsel performansa, ekonomik büyümeye ve rekabete olan etkileri incelenmiştir. Literatür değerlendirildiğinde, genel anlamda ekonomik özgürlüğün ekonomik büyümeyi, gelir düzeyinin artmasını, ekonomik kalkınmayı ve ekonomik performansı sağladığı, girişimcilik boyutunun ise inovasyonu, örgütsel performansı, ekonomik büyümeyi ve rekabeti pozitif yönlü ve anlamlı olarak etkilediği tespit edilmiştir. Dolayısıyla literatür, ekonomik özgürlüğün belirtilen boyutları sağlamasının teorik temelini sağlamlaştırmış olup, söz konusu teorik temellerin kanıksanmasına katkı sağlamıştır.

Ekonomik özgürlük ile girişimcilik boyutları arasında ilişkileri inceleyen çalışmalar değerlendirildiğinde, söz konusu boyutlar arasındaki ilişkiye ait veriler çoğunlukla ülkelere ve bölgelere ait üzerinden sağlanmıştır. Ayrıca araştırmalarda, ekonomik özgürlük ve girişimcilik boyutlarını oluşturan çoğu bileşenlerin 


\section{F. F. Altıntaş 13/2 (2021) 1835-1855}

birbirlerinden farklı olduğu tespit edilmiştir. Bu kapsamda Sobel, Clark ve Lee (2007), 2002 yılı için OECD ülkelerine ait veriler üzerinden girişimcilik ile ekonomik özgürlük boyutları arasındaki ilişkiyi araştırmışlardır. Araştırmada bağımlı değişkenler olarak KGM bileşenleri, bağımsız değişkenler olarak ekonomik özgürlük kapsamında uluslararası engeller ve yurtiçi engeller olarak değinilmiştir. Araştırmada ekonomik özgürlükler kapsamında hem uluslararası hem de yerel rekabetin önündeki engellerin bir ekonomide girişimcilik faaliyetleri üzerinde güçlü bir olumsuz etkiye sahip olduğu sonucuna ulaşılmıştır. Araştırmada özellikle yurtiçi engellemelerin uluslararası engellemelere kıyasla girişimciliği daha fazla azalttığı belirtilmiştir.

Gwartney ve Lawson (2003), OECD ülkeleri üzerinde yaptığı araştırmada, ekonomik özgürlüğün, girişimciliği anlamlı ve pozitif yönde etkilediği bulgusuna ulaşılmıştır. Bu kapsamda araştırmada, daha fazla ekonomik özgürlüğe sahip ülkeler daha üretken ve girişimcilik faaliyetlerinde söz sahibi olduğu, buna karşın uygun olmayan ekonomik müdahaleler ile daha az ekonomik özgürlüğe sahip olan ülkelerde ise girişimcilik faaliyetlerin az olduğu bulgusuna varılmıştır.

Ovaska ve Sobel (2005), ekonomik özgürlük ile ilişkili olan çeşitli ülkelere ait kredi alt yapısı, kredi verme performansı, yabancı sermaye akışı ve sınırlı devlet yapısı durumlarını açıklayan veriler kapsamında, söz konusu ekonomik özgürlük ile ilişkili olan değişkenlerin girişimciliğe olan etkisini araştırmışlardır. Bulgulara göre, sadece kredi verme performansının girişimciliği artırdığı, buna karşın diğer değişkenlerin girişimciliği sağlayamadığı sonucuna ulaşılmıştır.

Freytag ve Thurik (2007), 2004 yılı için Avrupa Birliği ve ABD ülkelerine ait ilgili değerler üzerinden kurumsal yapılar ile girişimcilik arasındaki ilişkiyi değerlendirmişlerdir. Araştırmacılar, bağımsız değişkenler olarak kurumsal yapılar kapsamında ekonomik özgürlük, hayat beklentisi, GSMH, sınırlı devlet yapısı, bağımlı değişkenler olarak ise girişimcilik kapsamında girişimcilik tercihini ve fiili girişimcilik boyutlarını ele almışlardır. Araştırma bulgularına göre; ekonomik özgürlügün, hayat beklentisinin, GSMH'nın ve devlet yapısının girişimcilik tercihi ile fiili girişimciliği sağlamadığı ifade edilmiştir.

Bjørnskov ve Foss (2008), 2001 yılı için 29 ülkeye ait KGM ve EÖE'sini oluşturan bileşenlere ait veriler üzerinden ekonomik özgürlük ile girişimcilik arasındaki ilişkiyi incelemişlerdir. Bulgulara göre, ekonomik özgürlükler kapsamında sınırlı devlet ve mali sağlamlık değişkenlerinin girişimcilik değişkenleri ile anlamlı ve pozitif yönlü ilişkileri olduğu, buna karşın serbest piyasa, hukukun üstünlüğü, uluslararası ticaret ve bürokrasi etkinliği değişkenleri ile girişimcilik boyutu değişkenleri arasında anlamlı bir ilişkinin olmadığ1 tespit edilmiştir. Devamında, araştırma kapsamında sınırlı devlet ve mali sağlamlık değişkenlerinin mal piyasalarındaki rekabeti ve verimliliği sağlaması, girişimciliğe olumlu etkisinin olduğu değerlendirilmiştir.

Nystörn (2008), 1972-2002 yıl aralığındaki OECD ülkelerine ait ekonomik özgürlük ve girişimcilik boyutlarına ait ilgili veriler üzerinden ekonomik özgürlük ve girişimcilik boyutları arasındaki ilişkiyi araştırmıştır. Araştırmada sınırlı devlet, yasal yapılar ve mülkiyet hakların korunması değişkenlerinin girişimciliği sağlamasındaki önemi vurgulanmıştır.

McMullen, Bagby ve Palich (2008), 37 ülkenin 2003 yılı için EÖE'de ve 2002 yılı için ise KGM'de belirtilen bazı ilgili değişkenlere ait değerler üzerinden gayri safi milli hasılanın (GSMH) ve ekonomik özgürlügün, fırsat motiveli ile gereksinim motiveli girişimcilik boyutlar arasındaki ilişkiyi incelemişlerdir. Araştırma bulgularına göre, GSMH değişkeninin fırsat motiveli ve gereksinim motiveli girişimcilik faaliyetleri ile negatif yönlü anlamlı ilişkilerin olduğu tespit edilmiştir. Araştırmada ayrıca gereksinim motiveli girişimciliğin ekonomik özgürlük kapsamında finansal özgürlük, yoksulluğun olmaması, iş özgürlüğü, mülkiyet haklarının korunması, yatırım özgürlüğü ve ticaret özgürlüğü değişkenleri ile anlamlı ve pozitif yönlü ilişkilerin olduğu, buna karşın mali özgürlük, sınırlı devlet ve parasal özgürlük ile anlamlı ilişkilerin olmadığı belirtilmiştir. Fırsat motiveli girişimciliğin ise hiçbir ekonomik özgürlük değişkeni ile anlamlı ilişkilerin olmadığ1 açıklanmıştır. Buna göre, fırsat motiveli girişimciliğin ekonomik özgürlük değişkenleri ile anlamlı ilişkilerin olması, özellikle gelişmiş ülkelerde yeni niş pazarların ve ekonomik sektörlerin sağlanabileceği vurgulanmıştır. Ayrıca araştırmada, gereksinim motiveli girişimciliğin, çevresel değişkenlerin çok olduğu ve buna bağlı olarak gereksinim motiveli girişimciliğin sağlanmasında ekonomik özgürlüklerin çevresel kararlılığına dikkat edilmesi gerektiği ifade edilmiştir. 
Sobel (2008), ABD'lerindeki 48 eyalete ait verilere istinaden ekonomik özgürlük ile üretken ve üretken olmayan girişimcilik değişkenleri ile olan ilişkilerini incelemişlerdir. Araştırma sonucuna göre, ekonomik özgürlüğün üretken olan ve üretken olmayan girişimcilik değişkenleri ile pozitif yönlü anlamlı ilişkileri olduğu sonucuna ulaşılmıştır. Buna göre araştırmada, girişimciliğin sağlanmasında ekonomik özgürlügün önemi vurgulanmıştır.

Djankov vd. (2009), ekonomik özgürlük ile ilişkisi olan vergi oranları, GSMH, satış vergisi, devlet sınırları, etkin vergi uygulamaları, yabancı yatırımlara olan açıklık ve enflasyon değişkenlerinin girişimciliğe olan etkisini araştırmışlardır. Araştırma bulgularına göre, özellikle vergi kapsamında efektif kurumlar vergisinin kurumsal girişimcilik ve yatırım üzerinde olumsuz bir etkiye sahip olduğu değerlendirilmiştir. Bunun yanında, araştırma kapsamında uygun devlet müdahalesinin, GSMH artışının ve yabancı yatırımcılara olan açıklığın girişimciliği sağladığı sonucuna varılmıştır.

Stenholm, Acs ve Wuebker (2013), 2008 ve 2009 yılları için toplam 63 ülkenin KGE'ni ve KGM'nü oluşturan bileşenlere ait değerler üzerinden ülkelerin düzenleyici işlemlerinin yine ülkelerin girişimciliğe faaliyeti oranlarına ve girişimcilik faaliyet tiplerine olan etkilerini değerlendirmişlerdir. Ayrıca araştırmada ülkelerin düzenleyici işlemlerin göstergeleri, ülkelerin EÖE çerçevesinde açılanan bileşenler oluşturmuştur. Araştırma sonucuna göre, düzenleyici işlemlerin girişimciliğe faaliyeti oranlarına olumlu ve pozitif yönde etkilediği sonucuna ulaşılmıştır. Buna karşın, düzenleyici işlemlerin girişimcilik faaliyet tiplerini oluşturmadığı tespit edilmiştir. Araştırmacılar bu sonuçlara göre, genel anlamda yenilikçi olan ve hızlı büyüyen yeni girişimcilerin oluşumu için düzenleyici ortamın iyileştirilmesi gerektiğinin yanında, yüksek etkililik seviyesinde girişimcilik için bilgi yayılmaların sağladığı yeni fırsatla ile dolu kurumsal ortamın ve sermayenin önceliğinden bahsetmişlerdir.

Weber ve Powell (2013), 1981-2009 yıl aralığındaki 50 ülkeye ait ilgili ekonomik özgürlük ve girişimcilik verilerine istinaden ekonomik özgürlüğün girişimciliğe olan etkisini araştırmışlardır. Bulgulara göre, ekonomik özgürlüğün girişimcilik sermeyesi, GSMH ve kişisel mülkiyet oranı ile anlamlı ilişkilerin olmadığı tespit edilmiştir.

Karabıyık ve Çilbant (2017), 2006-2015 yıl aralı̆̆ındaki 35 ülkenin ekonomik özgürlük kapsamında yatırım özgürlüklerinin, mülkiyet haklarının ve vergi yüklerinin girişimcilik boyutu ile olan ilişkilerini incelemişlerdir. Bulgulara göre, sadece yatırım özgürlüğü değişkeninin girişimciliğe anlamlı ve pozitif yönde etkisinin olduğu sonucuna ulaşılmıştır.

Gül ve Gül (2018), 2012-2017 yılları arasında Balıkesir ilindeki KOSKEB kuruluşundan kredi sağlayan 60 kadın girişimciden elde ettikleri verilere göre söz konusu kadın girişimcilere göre en önemli girişimcilik özelliklerini tespit etmişlerdir. Araştırma sonucuna göre, en önemli girişimcilik özelliklerinin ekonomik özgürlük, başarılı olma ve özgüven sağlama olduğu ifade edilmiştir.

Literatür değerlendirildiğinde, ekonomik özgürlükler ile girişimcilik boyutları arasındaki ilişkileri açıklayan çalışmaların sınırlı olduğu değerlendirilmiştir. Bu kapsamda özgürlük ve girişimcilik boyutlarının birbirleri ile olan ilişkilerini konu alan daha çok araştırma yapılması ihtiyacı doğduğu düşünülmüştür. Çünkü ekonomik özgürlüğün girişimciliği etkilemesine yönelik yapılacak olan spesifik çalışmalar ile hangi durumlarda ve koşullarda ekonomik özgürlük boyutunun girişimciliği sağladığı veya sağlamadığı nedensonuç analizi çerçevesinde daha sağlıklı ve çok yönlü olarak değerlendirilebilecektir.

\section{Yöntem}

\subsection{Araştırmanın Amacı, Veri Seti, Verilerin Analizi ve Modeli}

Araştırmanın amacı, ekonomik özgürlük boyutunun girişimcilik boyutuna olan etkileme değerini, ekonomik özgürlük boyutunun girişimcilik boyutunu etkilemesindeki faktörlerin (değişkeni) hassaslık ve faktörlerin önemlilik değerlerini (etkisel yapıya katkı değerlerini) tespit etmektir.

Ülkelerin ekonomik özgürlük performansları en son ve güncel haliyle EÖE kapsamında 2020 yılı için ülkeler bazında yayımlanmıştır. Buna karşın ülkelerin girişimcilik performansları ise KGE kapsamında 2020 yılı için şu ana kadar rapor oluşturulmamıştır. Bu kapsamda araştırmada yıl bazında tutarlılık göstermesi açısından 2020 yılına en yakın yıl olan 2019 yılı verileri tercih edilmiştir. Dolayısıyla araştırmanın veri seti, 2019 yılı için EÖE ve KGE raporlarında bulunan 115 ülkeye ait her iki endeks faktörlerine ait değerlerden oluşmaktadır. 


\section{F. F. Altıntaş 13/2 (2021) 1835-1855}

Ülkelere ait EÖE faktörlerine ait değerler www.heritage.org, KGE bileşenlerine ait değerler ise wwww.thegedi.org internet adreslerinden temin edilmiştir. Ayrıca araştırma verileri 2019 yılı Aralık ayında elde edilmiştir. Araştırmada kolaylık sağlaması için EÖE ve KGE faktörlerine ait bileşenlerin kısaltmaları Tablo 3'de gösterilmiştir.

Tablo 3. EÖE ve KGE Faktörleri ile Faktörlere Ait Bileşenlerin Kisaltmalar

\begin{tabular}{|l|l|l|l|}
\hline EÖE Faktörleri & Kısaltma & KGE Faktörleri & Kisaltma \\
\hline Hukukun Üstünlüğü & HUF & Girişimsel Tutumlar & GTAD \\
\hline Sinırlı Devlet & SDF & Girişimsel Yetenekler & GYAD \\
\hline Bürokrasi Etkinliği & BEF & \multirow{2}{*}{ Girişimsel Amaçlar } & GAAD \\
\hline Açık Pazar & APF & & \\
\hline
\end{tabular}

Tablo 3'de belirtilen EÖE ve KGE faktör değerleri, söz konusu faktörlere ait bileşenlerin aritmetik ortalamaları alınarak hesaplanmıştır. Araştırmada ayrıca literatüre dayanılarak ekonomik özgürlük boyutunun girişimcilik boyutunu etkilemesine ilişkin olarak model oluşturulmuştur. Araştırmada, modele ilişkin olarak oluşturulan amaçların tespitinde yapısal eşitlik modellemesinden yararlanılmıştır. Verilerin tespit edilmesinde IBM SPSS 21 AMOS programından yararlanılmış olup, söz konusu model Şekil 1'de gösterilmiştir.

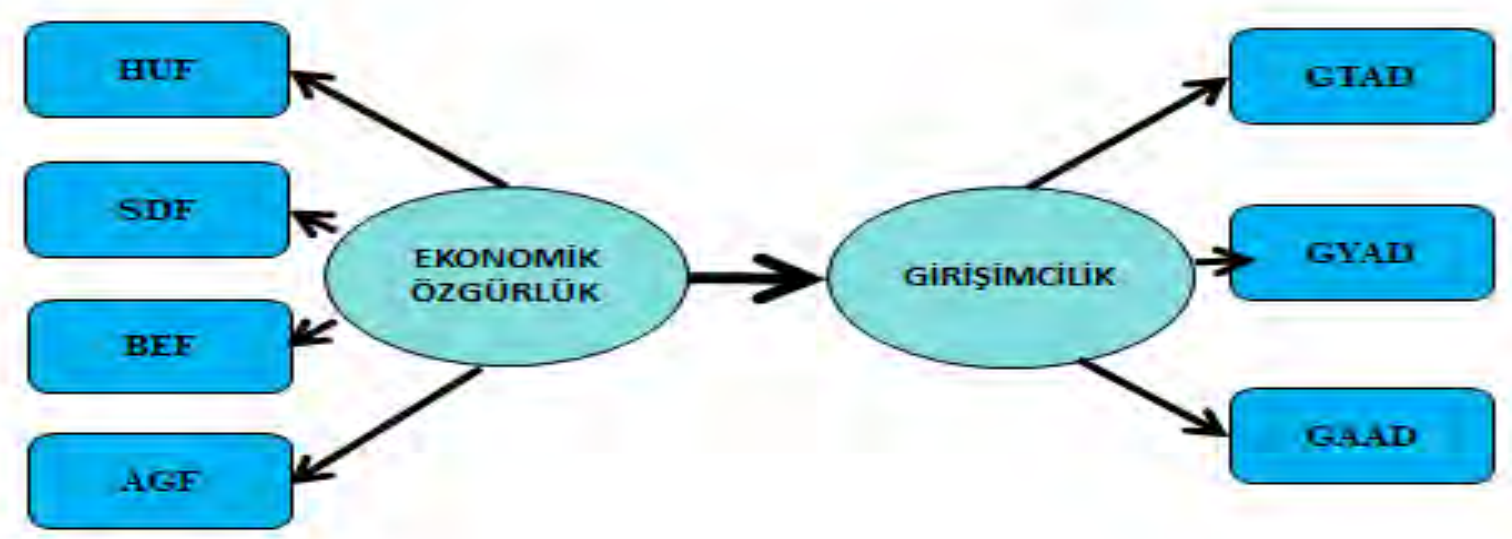

Şekil 1. Araştırma Modeli

\subsection{Araştırmanın Önemi ve Katkısı}

Ulusal ve uluslararası literatür değerlendirildiğinde, 2019 yılı için her iki rapor kapsamındaki ülkelerin EÖE ve KGE göstergeleri ile ekonomik özgürlük ve girişimcilik boyutları arasındaki ilişkiyi yapısal eşitlik modellemesi ile açıklayan bir araştırmaya rastlanılmamıştır. Dolayısıyla bu araştırma, belirtilen özelliklere uyan literatürde bulunan ilk araştırmadır. Araştırma sonucunda tespit edilen bulgular araştırmacılar için bir veri seti niteliği taşımaktadır.

\section{Bulgular}

Araştırmada araştırmanın modelini doğrulayacak yol analizinden önce faktör ağırlıklarının faktörleri temsil etme seviyelerini hesaplamak ve araştırmanın modelinin uygunluğunu ölçmek için Doğrulayıcı Faktör Analizi (DFA) işleminin yapılması gerekmektedir. Buna bağlı olarak DFA işleminde; ilişkisiz düzey, tek faktörlü düzey, birincil düzey ve ikincil düzey modelleri test edilerek söz konusu modellerden hangisinin en iyi uyumun sağladığı belirlenir (Meydan ve Şeşen, 2015: 25). Buna bağlı olarak uyum iyiliği değerleri ile araştırma modeline göre DFA modellerinin uyum iyiliği değerleri Tablo 4'de açıklanmıştır. 


\section{F. F. Altıntaş 13/2 (2021) 1835-1855}

Tablo 4. DFA Modelleri Uyum İyiliği Değerleri

\begin{tabular}{|l|l|l|l|l|l|l|}
\hline Ölçüm & İyi Uyum & $\begin{array}{l}\text { Kabul } \\
\text { Edilebilir Uyum }\end{array}$ & İlişkisiz & $\begin{array}{l}\text { İkincil } \\
\text { Seviye }\end{array}$ & $\begin{array}{l}\text { Tek } \\
\text { Faktörlü }\end{array}$ & $\begin{array}{l}\text { Birincil } \\
\text { Seviye }\end{array}$ \\
\hline Ki-kare( $\left.\boldsymbol{X}^{2}\right)$ & $0 \leq \mathrm{X}^{2} \leq 2 . \mathrm{sd}$ & $2 . \mathrm{sd} \leq \mathrm{X}^{2} \leq 3 . \mathrm{sd}$ & 105,1 & 110,2 & 99,23 & 32,259 \\
\hline Anlamlılık $(\boldsymbol{p})$ & $0,05<p \leq 1,00$ & $0,01<p \leq 0,05$ & 0,035 & 0,07 & 0,03 & 0,06 \\
\hline Kikare/sd $\left(\boldsymbol{X}^{2} / \mathrm{sd}\right)$ & $0 \leq \mathrm{X}^{2} / \mathrm{sd} \leq 2$ & $2 \leq \mathrm{X}^{2} / \mathrm{sd} \leq 3$ & 0,913 & 0,958 & 0,862 & 0,28 \\
\hline SRMR & $0 \leq \mathrm{SRMR} \leq 0,05$ & $0,05 \leq \mathrm{SRMR} \leq 0,10$ & 0,09 & 0,1 & 0,08 & 0,07 \\
\hline GFI & $0,950 \leq \mathrm{GFI} \leq 1$ & $0,90 \leq \mathrm{GFI} \leq 0,95$ & 0,9 & 0,89 & 0,9 & 0,923 \\
\hline AGFI & $0,90 \leq \mathrm{AGFI} \leq 1,00$ & $0,85 \leq \mathrm{AGFI} \leq 0,90$ & 0,87 & 0,85 & 0,89 & 0,91 \\
\hline NFI & $0,95 \leq \mathrm{NFI} \leq 1,00$ & $0,90 \leq \mathrm{NFI} \leq 0,95$ & 0,92 & 0 & 0,93 & 0,96 \\
\hline CFI & $0,97 \leq \mathrm{CFI} \leq 1,00$ & $0,95 \leq \mathrm{NFI} \leq 0,97$ & 0,91 & 0,9 & 0,94 & 0,976 \\
\hline RMSEA & $0 \leq \mathrm{RMSA} \leq 0,05$ & $0,05 \leq \mathrm{RMSA} \leq 0,08$ & 0,07 & 0,085 & 0,065 & 0,06 \\
\hline
\end{tabular}

Tablo 4'e göre, birincil seviye DFA Ki-kare ( $\left.\mathrm{X}^{2}\right)$, Anlamlllık (p), Kikare/sd (X²/sd), AGFI, NFI ve CFI ölçümleri için iyi uyum, kalan diğer göstergeler için kabul edilebilir iyi uyum göstermiştir. Buna bağlı olarak ayrıca birincil seviye DFA ölçüm sonuçları, diğer DFA modellerinin DFA ölçüm sonuçlarına göre iyi uyum değerine daha yakın olduğu için DFA modellerinden birincil seviye DFA, diğer DFA modellerine göre araştırma modelinin uygunluğunu daha iyi yansıtmaktadır. Bunun yanında, birincil seviye DFA modeli ölçümleri uyum değerleri sağladığı için modifikasyon işlemine ihtiyaç duyulmamıştır.

DFA kapsamında bileşim ve ayrışım geçerliliğinin hesaplanması gerekmektedir. Bileşim ve ayrışım geçerliliğinin tespiti için ilgili değişkenler arasındaki Birleşik Güvenirlilik Katsayı (CR) ve Açıklanan Ortalama Varyans (AVE) değerleri aranmaktadır (Büyükyılmaz ve Fidan, 2017: 512). DFA'nde bileşim geçerliliğinin sağlanması için CR niceliğinin 0,700, AVE niceliğinin ise 0,500 değerinden büyük değerde olmaları ve bunun yanında, CR değerinin AVE değerinden büyük olması gerekmektedir. Ayrışım geçerliliğ̈inin sağlanması için ise AVE değerinin karakök değerinin, faktörler arasındaki ilişki değerinden büyük olmalıdır (Fornell ve Lacker, 1981; Hair vd, 1998). Buna bağlı olarak tespit edilen değerler Tablo 5'de açıklanmıştır.

Tablo 5. Bileşim ve Ayrışım Geçerliliği Sağlanmasında Tespit Edilen Değerler

\begin{tabular}{|c|c|c|c|c|c|c|c|c|}
\hline Endeksler & Faktörler & Ortalamalar & $\begin{array}{l}\text { Standart } \\
\text { Sapmalar }\end{array}$ & $\begin{array}{l}\text { Cronbabach } \\
\text { Alpha }\end{array}$ & CR & AVE & \begin{tabular}{|l} 
AVE \\
Karakök \\
\end{tabular} & Korelasyon \\
\hline \multirow{4}{*}{ EÖE } & HUF & 36,363 & 18,871 & \multirow{7}{*}{0,940} & \multirow{4}{*}{0,964} & \multirow{4}{*}{0,925} & \multirow{4}{*}{0,961} & \multirow{7}{*}{0,960} \\
\hline & SDF & 36,322 & 20,751 & & & & & \\
\hline & BEF & 36,622 & 21,749 & & & & & \\
\hline & APF & 52,548 & 17,547 & & & & & \\
\hline \multirow{3}{*}{ KGE } & GAAD & 70,676 & 12,794 & & \multirow{3}{*}{0,977} & \multirow{3}{*}{0,934} & \multirow{3}{*}{0,988} & \\
\hline & GYAD & 69,135 & 8,053 & & & & & \\
\hline & GTAD & 67,062 & 11,998 & & & & & \\
\hline
\end{tabular}

Tablo 5'de, EÖE ile KGE'nin faktörlerine ait CR değerlerinin 0,500 ve ilgili faktörlere ait AVE değerlerinin 0,700 değerinden yüksek olduğu ve endekslere ait CR değerleri AVE değerlerinden yüksek olduğu belirtilmiştir. Ayrıca endekslere ait AVE karakök değerleri, endeksler arasındaki korelasyon değerinden büyük olduğu tespit edilmiştir. Dolayısıyla Tablo 5'de belirtilen değerlere göre söz konusu modelin bileşim ve ayrışım geçerliliği oluşturulmuştur.

Tablo 6. Endekslerin ve Faktörlerin Hata Terimlerin Varyanslarına Ait Değerler

\begin{tabular}{|l|l|l|l|l|}
\hline Endeksler ve Faktörler & Varyans & Standart Hata & t & p \\
\hline EÖE & 265,511 & 40,933 & 6,486 & $* * *$ \\
\hline KGE & 413,961 & 61,901 & 6,687 & $* * *$ \\
\hline e1 $\rightarrow$ HUF & 39,733 & 9,813 & 4,049 & $* * *$ \\
\hline e2 $\rightarrow$ SDF & 156,074 & 20,717 & 7,534 & $* * *$ \\
\hline e3 $\rightarrow$ BEF & 27,686 & 3,962 & 6,989 & $* * *$ \\
\hline e4 $\rightarrow$ APF & 59,645 & 8,583 & 6,949 & $* * *$ \\
\hline
\end{tabular}




\begin{tabular}{|l|l|l|l|l|} 
e5 $\rightarrow$ GADD & 54,968 & 8,944 & 6,146 & $* * *$ \\
\hline e6 $\rightarrow$ GYAD & 9,845 & 5,056 & 1,947 & $* * *$ \\
\hline e7 $\rightarrow$ GTAD & 58,511 & 8,716 & 6,713 & $* * *$ \\
\hline
\end{tabular}

$* * *=\mathrm{p}<.001$

Tablo 6'da endekslere ve faktörlere ait varyans değerleri açıklanmıştır. Tablo 6'ya göre, faktörlerin ve göstergelerin varyans değerlerinin hepsi anlamlı olarak hesaplanmıştır $\left(^{* * *}=\mathrm{p}<.001\right)$. Tablo 6'ya göre, EÖE'nin (gizil değişken) kendi faktörlerine (gözlemlenen değişkenler) ait varyans değeri, KGE'nin (gizil değişken) kendi faktörlerine (gözlemlenen değişkenler) ait varyans değerinden az çıkmıştır (EÖEvaryans=40,933 < KGEvaryans=61,9016). Bu durum, ekonomik özgürlük boyutunun (gizil değişken) kendi faktörlerine (gözlemlenen değişkenler) ait varyans yakınlığı, girişimcilik boyutunun kendi faktörlerine olan varyans yakınlığından fazla olduğunu açıklamaktadır. Aynı zamanda Tablo 6'ya göre, EÖE kapsamında BEF faktörünün, KGE kapsamında ise GYAD faktörünün varyans değeri, diğer faktörlerin varyans değerlerine göre daha az olduğu tespit edilmiştir $\left(\mathrm{BEF}_{\text {Varyans }}=27,686, \mathrm{GYADVaryans}=9,845<\right.$ Diğer Göstergeler). Bu durum ise $\mathrm{BEF}$ ve KGE faktörlerinin kendi hata terimine olan varyans yakınlı̆̆ı, diğer göstergelerin kendi hata terimlerine ait varyans yakınlığından fazla olduğunu göstermektedir.

Tablo 7. Faktörlere Ait Korelasyon Değerleri

\begin{tabular}{|l|l|l|l|l|l|l|l|}
\hline Faktörler & GTAD & GYAD & GAAD & HUF & SDF & BEF & APF \\
\hline GTAD & 1 & & & & & & \\
\hline GYAD & $0,900^{* *}$ & 1 & & & & & \\
\hline GAAD & $0,844^{* *}$ & $0,932^{* *}$ & 1 & & & & \\
\hline HUF & $0,850^{* *}$ & $0,880^{* *}$ & $0,838^{* *}$ & 1 & & & \\
\hline SDF & $0,400^{*}$ & $0,432^{*}$ & $0,403^{*}$ & $0,486^{*}$ & 1 & & \\
\hline BEF & $0,689^{* *}$ & $0,688^{* *}$ & $0,612^{* *}$ & $0,729^{* *}$ & $0,419^{*}$ & 1 & \\
\hline APF & $0,723^{* *}$ & $0,739^{* *}$ & $0,678^{* *}$ & $0,683^{* *}$ & $0,443^{*}$ & $0,631^{* *}$ & 1 \\
\hline
\end{tabular}

$* \mathrm{p}<.05,{ }^{* *}=\mathrm{p}<.01$

Tablo 7'de faktörlerin birbirleri arasındaki korelasyon değerleri sunulmuştur. Tablo 7'ye göre, tüm faktörler arasındaki korelasyon değerlerin pozitif yönlü ve anlamlı olduğu $\left({ }^{*}=p<.05, p^{* *}=<.01\right)$ ve faktörler değerlerinin genel olarak orta ve yüksek düzeyde olduğu tespit edilmiştir. Dolayısıyla bu durum, EÖE ve KGE faktörlerinin birbirlerini tamamlayan bütünleşik bir yapıda olduğunu göstermektedir.

Şekil 1'de belirtilen modelin doğruluğunu tespit etmek ve buna göre ekonomik özgürlük boyutunun girişimcilik boyutunu etkilemesine yönelik ilişkinin tespiti için yol analizi metodu uygulanmıştır. Bu kapsamda oluşturulan modele ilişkin yol analizi diyagramı Şekil 2' de gösterilmiştir.

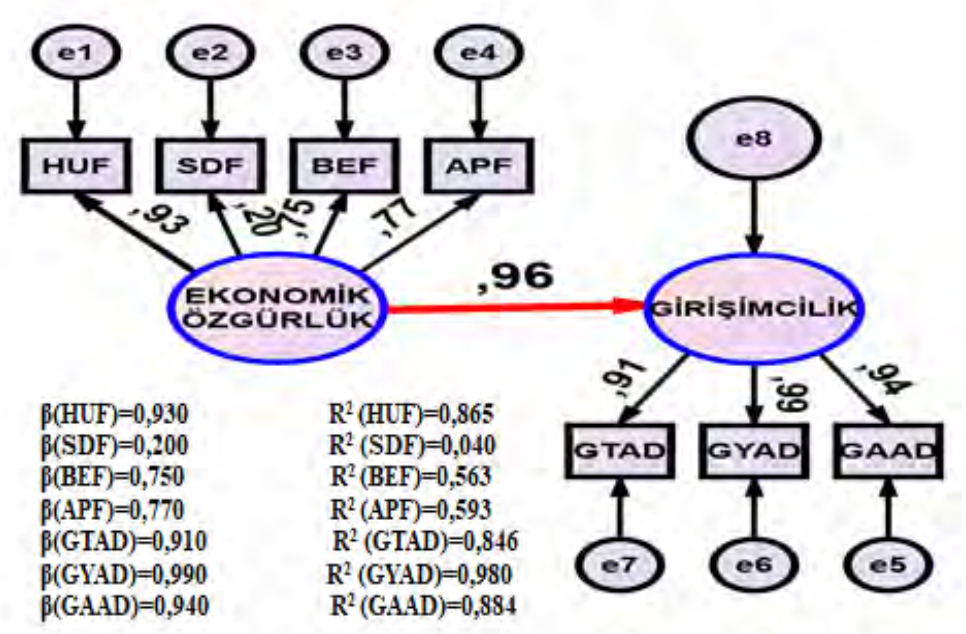

Şekil 2. Modele İlişkin Standart Yol Analizi Diyagramı 
Birincil seviye doğrulayıcı faktör analizi modeli, boyutlar arası (gizil değişkenler) arasında ilişki yapısını açıklamaktadır. Dolayısıyla Şekil 2'de gösterilen yol analizi yine söz konusu boyutlar arasındaki ilişki modelini (etki değerini) açıkladığı için yol analizi modelinin uyum iyiliği değerleri ile birincil seviye doğrulayıcı faktör analizinin uyum iyiliği değerleri aynı çıkmıştır. Yol analizinde standart olmayan regresyon değerleri, boyutların (gizil değişkenlerin) değişiminin, boyutları etkilediği faktörlerde (gözlemlenen değişkenlerde) ve diğer boyutlarda nasıl bir değişim oluşturduğu göstermektedir. Dolayısıyla standart olmayan regresyon değerleri ile boyutlar ve boyutların etkilediği faktörler arasında doğrusal denklemler oluşturulabilmektedir. Bu kapsamda yol analizine göre tespit edilen standart olmayan değerler ve değerlere göre oluşturulan denklemler Tablo 9'da belirtilmiştir.

Tablo 9. Standart Olmayan Regresyon Değerleri

\begin{tabular}{|c|c|c|c|c|c|c|}
\hline \multicolumn{2}{|c|}{ Boyut ve Faktörler } & \multirow{2}{*}{$\begin{array}{l}\text { Boyutlar } \\
\text { Ekonomik Özgürlük }\end{array}$} & \multirow{2}{*}{$\frac{\text { Değer }}{1,195}$} & \multirow{2}{*}{$\begin{array}{l}\text { Standart Hata } \\
0,077\end{array}$} & \multirow{2}{*}{$\frac{t}{15,434}$} & \multirow{2}{*}{$\frac{\mathrm{p}}{* * *}$} \\
\hline Girişimcilik & $<---$ & & & & & \\
\hline HUF & $<---$ & Ekonomik Özgürlük & 1 & ------ & ------ & ------ \\
\hline SDF & $<---$ & Ekonomik Özgürlük & 0,153 & 0,074 & 2,066 & 0,039 \\
\hline BEF & $<--$ & Ekonomik Özgürlük & 0,371 & 0,034 & 10,77 & $* * *$ \\
\hline APF & $<---$ & Ekonomik Özgürlük & 0,563 & 0,051 & 11,057 & $* * *$ \\
\hline GAAD & $<---$ & Girişimcilik & 1 & ----- & ------ & ------ \\
\hline GYAD & $<---$ & Girişimcilik & 1,004 & 0,039 & 25,879 & $* * *$ \\
\hline GTAD & <--- & Girişimcilik & 0,844 & 0,046 & 18,354 & $* * *$ \\
\hline \multicolumn{7}{|l|}{ Denklemler } \\
\hline Girişimcilik & $<---$ & Ekonomik Özgürlük & \multicolumn{4}{|c|}{ Girişimcilik=Ekonomik Özgürlük.(1,195)+e8 } \\
\hline HUF & $<<--$ & Ekonomik Özgürlük & \multicolumn{4}{|c|}{ HUF = Ekonomik Özgürlük.(1)+e1 } \\
\hline SDF & $<---$ & Ekonomik Özgürlük & \multicolumn{4}{|c|}{ SDF =Ekonomik Özgürlük.(0,153)+e2 } \\
\hline BEF & $<---$ & Ekonomik Özgürlük & \multicolumn{4}{|c|}{ BEF=Ekonomik Özgürlük.(0,371)+e3 } \\
\hline $\mathrm{APF}$ & $<---$ & Ekonomik Özgürlük & \multicolumn{4}{|c|}{ APF=Ekonomik Özgürlük. $(0,563)+\mathrm{e} 4$} \\
\hline GAAD & $<---$ & Girişimcilik & \multicolumn{4}{|c|}{ GAAD $=$ Girişimcilik.(1)+e5 } \\
\hline GYAD & $<---$ & Girişimcilik & \multicolumn{4}{|c|}{ GYAD = Girişimcilik. $(1,004)+\mathrm{e} 6$} \\
\hline GTAD & $<---$ & Girişimcilik & \multicolumn{4}{|c|}{ GTAD = Girissimcilik. $(0,844)+\mathrm{e}$} \\
\hline
\end{tabular}

Tablo 9'a göre, boyutların kendilerine ait faktörler ile olan etkisel değerlerin hepsinin pozitif yönlü ve anlamlı $\left(^{* * *}=\mathrm{p}<.01\right)$ olduğu tespit edilmiştir. Tablo 9 değerlendirildiğinde, ekonomik özgürlük boyutunda bir birimlik artış sırasıyla girişimcilik boyutunda 1,195, $\mathrm{HUF}^{\prime}$ de $1, \mathrm{APF}^{\prime}$ de $0,563, \mathrm{BEF}^{\prime}$ de 0,371 ve $\mathrm{SDF}^{\prime}$ de 0,153 değerinde artış meydana getirmiştir. Dolayısıyla ekonomik özgürlük boyutu en fazla girişimcilik boyutu ve HUF faktöründe değişim meydana getirmiştir. Tablo 9 kapsamında bütün bunlara göre, faktör kapsamında HUF ekonomik özgürlük boyutunun girişimcilik boyutunu etkilemesinde diğer ekonomik özgürlük faktörlerine kıyasla en hassas, değişim ivmesi ile esneklik katsayısı en fazla, girişimcilik boyutuna ve girişimcilik boyutu faktörlerine en fazla etki ve tamamlayıcılık işlevi olan faktör olduğu tespit edilmiştir. Bunun nedeni olarak dünya ülkelerinin ekonomik özgürlükler kapsamında HUF kapsamında yaptıkları faaliyetler ile girişimcilik için yapılan faaliyetlerin birbirlerini ilgilendiren ve ortak noktalarının olmasından kaynaklandığ değerlendirilebilir. Diğer bir ifade ile dünya ülkelerin girişimcilik için oluşturulan hukuksal yapılanmanın işlevselliği girişimciliği sağladığı değerlendirilebilir.

Tablo 9'a göre, girişimcilik boyutu bir birimlik artış sırasıyla GYAD'da 1,004, GGAD'da 1 ve son olarak GTAD'da 0,884 birimlik artış meydana getirmiştir. Dolayısıyla bu durum GYAD'ın diğer girişimcilik faktörlerine göre ekonomik özgürlük boyutundan daha fazla etkilendiğini göstermektedir. Bunun yanında, GGAD ve GYAD girişimcilik faktörlerinin aralarında ekonomik özgürlük faktöründen etkilenme değeri olarak belirgin fark bulunmamaktadır. Buna bağlı olarak girişimsel yeteneklerin ve girişimsel amaçların, girişimsel tutumlara göre ekonomik yapılanmaya daha çok tepki vermektedir. Bunun sebebi ise girişimcilik yeteneğinin ve girişimcilik tutumların girişimcilik amaçlarına göre daha somut bir nitelik taşımasından kaynaklandığı düşünülebilir. 


\section{F. F. Altıntaş 13/2 (2021) 1835-1855}

Tablo 10. Standart Regresyon Değerleri

\begin{tabular}{|l|l|l|l|}
\hline \multicolumn{2}{|l|}{ Girişimcilik Boyutu ve Faktörler } & Faktörler (Gizil Değişkenler) & Değer \\
\hline Girişimcilik & $\leftarrow$ & Ekonomik Özgürlük & $\gamma_{\text {Ekonomik Özgürlük } \rightarrow \text { Girişimcilik }=0,960}$ \\
\hline HUF & $\leftarrow$ & Ekonomik Özgürlük & $\beta_{\text {Ekonomik Özgürlük } \rightarrow H U F=0,930}$ \\
\hline SDF & $\leftarrow$ & Ekonomik Özgürlük & $\beta_{\text {Ekonomik Özgürlük } \rightarrow \mathrm{SDF}=0,200}$ \\
\hline BEF & $\leftarrow$ & Ekonomik Özgürlük & $\beta_{\text {Ekonomik Özgürlük } \rightarrow \mathrm{BEF}=0,750}$ \\
\hline APF & $\leftarrow$ & Ekonomik Özgürlük & $\beta_{\text {Ekonomik Özgürlük } \rightarrow \mathrm{APF}=0,770}$ \\
\hline GAAD & $\leftarrow$ & Girişimcilik & $\beta_{\text {Girişimcilik } \rightarrow \mathrm{GAAD}=0,940}$ \\
\hline GYAD & $\leftarrow$ & Girişimcilik & $\beta_{\text {Girişimcilik } \rightarrow \mathrm{GYAD}=0,990}$ \\
\hline GTAD & $\leftarrow$ & Girişimcilik & $\beta_{\text {Girişimcilik } \rightarrow \mathrm{GTAD}=0,910}$ \\
\hline
\end{tabular}

Standart regresyon değerleri, bağımsız değișkenin standart sapmasında bir birimlik değișimin bağımlı değişkenin standart sapmasındaki değişim miktarını açıklamaktadır. Dolayısıyla standart regresyon katsayıları, boyutların (gizil değişkenlerin) birbirlerini etki değerlerini ve bağımsız değişkenler (gizil değişkenler, faktörler) için bağımlı değişkenlerin (gözlemlenen değişkenler, göstergeler) önemlilik değerlerini (etkisel yapıya katkı değerlerini) belirtmektedir. Tablo 10'a göre, ekonomik özgürlük boyutu girişimcilik

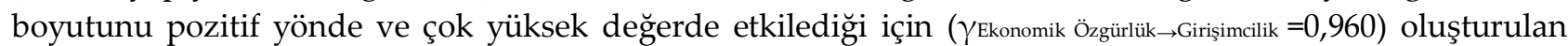
model doğrulanmıştır.

Tablo 7 değerlendirildiğinde, ekonomik özgürlük boyutunun kendi faktörlerini etkileme değerleri, faktörlerin etkisel yapıya katkı değerleri veya ekonomik özgürlük boyutunun girişimcilik boyutunu etkilemesinde ekonomik özgürlük boyutu için faktörlerin önemlilik değerleri (kendi faktörlerini etkileme değerleri) HUF $(\beta$ Ekonomik Özgürlük $\rightarrow \mathrm{HUF}=0,930)$, APF ( $\beta$ Ekonomik Özgürlük $\rightarrow$ APF $=0,770)$, BEF ( $\beta$ Ekonomik Özgürlük $\rightarrow B E F=0,750)$ ve SDF ( $\beta$ Ekonomik Özgürlük $\rightarrow$ SDF $=0,200$ ) olarak sıralanmıştır. Girişimcilik boyutunun kendi faktörlerini etkileme değerleri ise sırasıyla GYAD ( $\left.\beta_{\text {Girişimcilik } \rightarrow \text { GYAD }}=0,990\right)$, GAAD $\left(\beta_{\text {Girişismcilik } \rightarrow \text { GAAD }}=0,940\right)$ ve GTAD $\left(\beta_{\text {Grişimcilik } \rightarrow \text { GTAD }}=0,910\right)$ olarak belirlenmiştir. Genel anlamda değerlendirildiğinde ise ekonomik özgürlük boyutunun girişimcilik boyutunu etkilemesi kapsamında girişimcilik boyutunun kendi faktörlerini ortalama etkileme değeri, ekonomik özgürlük boyutunun kendi faktörlerini ortalama etkileme değerinden daha fazla olduğu için girişimcilik boyutu ekonomik özgürlük boyutuna göre ilişkisel yapıya (etkisel yapıya) daha fazla katkı sağlamıştır. Dolayısıyla bu durum, ekonomik özgürlük ile girişimciliğin sağlanmasının çok müsait ve mümkün olabileceğini göstermektedir.

Dünya ülkeleri açısından ekonomik özgürlük boyutunun girişimcilik boyutun etkilemesinde ekonomik özgürlük boyutu kapsamında HUF faktörünün (mülkiyet hakları, devlet bütünlüğü, yarg1 etkisi) diğer faktörlere göre anlamlılıklarının, önemliliklerinin ve önceliklerinin diğer göstergelere göre daha fazla olduğunu göstermektedir. Bunun nedeni, girişimcilik faaliyetlerinde fırsat eşitliğine, gereksiz bürokrasiye ve adalete daha çok gereksinim duyulmasından kaynaklanabilir. Ayrıca ekonomik özgürlük kapsamında SDF (sınırlı devlet) faktörünün girişimcilik boyutuna en az etki eden bir yapısı olduğu tespit edilmiştir. Bu durum, dünya genelinde ülkelerin ekonomik özgürlüklerin girişimciliği sağlamasına yönelik kısıtlı faaliyetlere sahip olduklarını göstermektedir. Girişimcilik boyutu kapsamında ise ekonomik özgürlüğün girişimciliği etkilemesine yönelik tüm girişimcilik faktörlerinin etkilenme yapısı çok yüksek düzeydedir. Özellikle GYAD faktörünün diğer faktörlere göre etkilenme yapısına katkı değeri en fazla olduğu tespit edilmiştir. Dolayısıyla bu durumun sebebi, girişimsel yetenekler kapsamında fırsat girişimlerinin, teknoloji emiliminin, insan kaynakları kalitesinin ve rekabetin ekonomik özgürlük ile oluşan faaliyetlerde daha çok belirginleşmiş olmasına bağlanabilir.

\section{Sonuç ve Tartışma}

Araştırmanın kavramsal çerçeve bölümünde ekonomik özgürlük, ekonomik özgürlük endeksi, girişimcilik ve girişimcilik endeksi ile ilgili olarak açıklamalarda bulunulmuştur. Literatürde ise ekonomik özgürlük boyutunun girişimcilik boyutunu etkilemesine yönelik ulusal ve uluslararası araştırmalar değerlendirilmiştir. Araştırmanın amacı, belirlenen model kapsamında ekonomik özgürlük boyutunun girişimcilik boyutuna olan etkisini ve buna bağlı olarak söz konusu etkisel yapıda en hassas faktörü (değişkeni) ve faktörlerin etkisel yapıya katkı değerlerini tespit etmektir. 
Araştırmada ilk olarak modelin yapıya uygunluğunu test etmek için doğrulayıcı faktör analizi uygulanmıştır. Söz konusu yapıya en uygun olan doğrulayıcı faktör analizinin birincil seviye doğrulayıcı faktör analizi olduğu değerlendirilmiştir. Bulgulara göre, ekonomik özgürlükler boyutunun girişimcilik boyutunu çok yüksek seviyede etkilemesi kapsamında oluşturulan modelin doğrulandığ 1 tespit edilmiştir. Araştırmada ekonomik özgürlükler kapsamında dünya ülkeleri için ekonomik özgürlük boyutunun girişimcilik boyutunu etkilemesinde en hassas göstergenin HUF olduğu bulgusuna ulaşılmıştır. Bu durum ayrıca ekonomik özgürlük boyutunun girişimcilik boyutunu etkilemesinde HUF ekonomik özgürlük faktörünün diğer ekonomik özgürlük faktörlerine göre etkisel kapsamının daha fazla olduğunu belirtmektedir. Bunun nedeni, dünya ülkelerinin HUF ile ilgili uygulamaları kapsamında yapmış oldukları faaliyetlerin girişimciliği sağlayacak bir oluşumu sağlamış olmalarından kaynaklandığı değerlendirilebilir. Dolayısıyla dünya ülkeleri öncelikli olarak girişimciliğin sağlanmasında temel anlamda ekonomik özgürlük temellerinden biri olan hukukun üstünlügüne daha çok yoğunlaşmışlardır. Aynı şekilde girişimcilik boyutu kapsamında dünya ülkeleri için girişimcilik boyutunun ekonomik özgürlük boyutundan etkilenmesinde ise en hassas göstergenin GYAD olduğu bulgusuna ulaşılmıştır. Bunun nedeni, girişimsel yetenekler faktörünün girişimsel amaçlar ve tutumlara göre sonuçsal niteliğinin daha çok belirginleşmiş olması kapsamında değerlendirilebilir.

Araştırma sonuçlarına göre, ekonomik özgürlük boyutunun, girişimcilik boyutunu çok yüksek seviyede etkilemesinden dolayı oluşturulan model doğrulanmıştır. Bu kapsamda, dünya ülkeleri açısından ekonomik özgürlük boyutunun girişimcilik boyutunu etkilemesinde ekonomik özgürlük boyutu kapsamında HUF faktörünün (mülkiyet hakları, devlet bütünlüğü, yargı etkisi) diğer faktörlere göre etkisel yapıya daha fazla katkı sağlamıştır. Bunun nedeni, hukuksal yapı destekli ekonomik özgürlüğün girişimcilik koşullarının herkes için sağlamasının öneminden kaynaklanabilir. Buna karşın SDF faktörü ekonomik özgürlüğün girişimciliğe sağlamasında en az katkı sağlayan bir yapısı olduğu tespit edilmiştir. Bunun nedeni ise serbest piyasa ekonomisi çerçevesinde ekonomik özgürlüklerin girişimciliği sağlamasına yönelik sınırlı olarak olanak sunan ülkelerin varlığının dünya ekonomisini etkileyebilmesinden kaynaklandığı değerlendirilebilir. Araştırmada ayrıca girişimcilik boyutu kapsamında GYAD faktörü etkilenme yapısına daha fazla katkı sağladığı tespit edilmiştir. Dolayısıyla girişimsel yetenekler ile ekonomik özgürlük kapsamında yapılan birbirlerini ilgilendiren faaliyetlerin öncelik olması ve buna bağlı olarak belirginleşmesi dünya ülkeleri için büyük önem kazanmıştır. Araştırmada ayrıca ekonomik özgürlük boyutunun girişimcilik boyutuna etkileme yapısına veya ekonomik özgürlük ile girişimcilik boyutları arasındaki ilişkisel yapıya girişimcilik boyutu ekonomik özgürlük boyutuna göre daha fazla katkı sağladığı gözlenmiştir. Bunun sebebi, dünya üzerinde girişimciliğin sağlanması için ekonomik özgürlüklere gereksinim duyulmasına bağlanabilir.

Literatür değerlendirildiğinde, ekonomik özgürlük ile girişimcilik boyutları arasındaki ilişkiyi açıklayan araştırmaların kısıtlı olduğu sonucuna ulaşılmıştır. Dolayısıyla genel anlamda bu çalışma, ekonomik özgürlüğün girişimciliği sağlamasına yönelik ampirik bulgular çerçevesinde literatüre katkı sağladığı değerlendirilebilir. Ayrıca ekonomik özgürlüğün girişimciliği etkilemesine yönelik bu çalışma, literatürde belirtilen Freytag ve Thurik (2007) ile Powell ve Weber'in (2013) çalışmaları haricinde diğer çalışmalar ile tutarlı bulgular taşımaktadır. Bunun dışında, ekonomik özgürlüğün girişimciliği etkilemesine yönelik ülkeler bazında elde edilen veriler kapsamında literatürde açıklanan Sobel (2008) ile Gül ve Gül'ün (2018) yapmış oldukları çalışmalar haricinde diğer araştırmalara ve yöntem bakımından ise ekonomik özgürlügün girişimciliği etkilemesine yönelik yapısal eşitlik modellemesinin kullanılması çerçevesinde Stenholm, Acs ve Wuebker' in (2010) araştırmasına benzerlik göstermiştir.

Genel anlamda öncelikli olarak dünya ülkeleri, ekonomik özgürlük faktörlerinin kendi arasındaki ilişkiler ile girişimcilik faktörlerinin kendi arasındaki ilişkilerin tamamlayıcılık faaliyetlerini artırarak ve buna bağlı olarak ekonomik özgürlük ve girişimcilik boyutlarının öz yapısındaki faktörler arasında etkileşimsel faaliyetleri sağlayarak ekonomik özgürlük ve girişimcilik boyutlarının daha tutarl, istikrarlı ve işlevsel olması sağlanabilir. Çünkü ekonomik özgürlük ve girişimcilik boyutlarından herhangi birinin veya her ikisinin kendilerine ait faktörler arasındaki bağımsızlığın, bağlantısızlığın, tamamlayıcılıksızlığın ve sonucunda oluşacak tutarsızlığın her ne kadar ekonomik özgürlük faktörlerinin girişimcilik faktörlerini anlamlı, pozitif yönde etkilese bile etkisel değer bir zaman sonra anlamını yitirecek ve ekonomik özgürlügün girişimciliği etkilemesinde etkileme kalitesi düşerek etkisel yapının istikrarının oluşmamasına neden olabilecektir.

İkinci olarak dünya ülkeleri genel anlamda ekonomik özgürlük ve girişimcilik boyutlarının birbirlerini ilgilendiren faaliyetler daha çok gerçekleştirerek ekonomik özgürlüğün girişimciliği etkilemesi daha anlamlı 


\section{F. F. Altıntaş 13/2 (2021) 1835-1855}

olması sağlanabilir. Böylelikle ülkeler, ekonomik özgürlük boyutunun hangi bileşeni/bileşenleri ile girişimciliğin oluşmasında daha fazla katkısı olabileceğini değerlendirebilirler. Buna bağlı olarak ülkeler, küresel anlamda ekonomik özgürlük ile girişimcilik boyutlarının daha çok gelişim sağlamasına neden olabilip, söz konusu boyutların sinerji özelliği kazanmasına neden olabilirler. Bu anlamda araştırmada SDF faktörünün girişimciliği sağlamada az etkisinin olması bulgusuna ulaşılması kapsamında ülkeler özellikle SDF faktörünün girişimciliği sağlayacak planlar, stratejiler, yöntemler ve yönetimler gerçekleştirebilirler. Dolayısıyla girişimciliği kısıtlı bırakan SDF faktörünün girişimciliği geliştirmesi yönünde ülkeler vergi politikalarına, kamu harcamalarına ve mali sağlamlılık yapısına önem vermelidirler.

Araştırmacılar için öneriler çerçevesinde, ülkelerin ekonomik özgürlük ve girişimcilik performanslarını ölçen diğer endeks veya metriklerden istifade edilerek ekonomik özgürlük boyutunun girişimcilik boyutu üzerindeki etkileri kıyaslanabilir. Dolayısıyla girişimcilik için ekonomik özgürlük boyutlarının niteliği nedensellik analizleri çerçevesinde daha anlamlı olarak değerlendirilebilir. Ayrıca ülkelerin ekonomik özgürlük ve girişimcilik performansının ölçülmesinde faktörlerin sayıları artırılabilir veya her ülkeye özgü faktörler oluşturulabilir. Buna bağlı olarak ülkelerin ekonomik özgürlük ve girişimcilik konusundaki yetenekleri, kapasiteleri ve potansiyelleri çok boyutlu olarak analiz edilerek ekonomik özgürlügün girişimcilik boyutuna olan etkisinin tespit edilmesinde daha gerçekçi sonuçlara ulaşılabilir.

\section{Kaynakça}

Acar, M. (2010). Serbest ticaret, ekonomik özgürlükler ve refah. Bilig(53), 1-23.

Ács, Z. J., Szerb, L., Lafuente, E., and Márkus, G. (2019). The Global Entrepreneurship Index. Washington, The Global Entrepreneurship and Development Institute.

Ács, Z., and Armington, C. (2004). Employment growth and entrepreneurial activity in cities. Regional Studies(38), 911-927.

Ács, Z., and Szerb, L. (2019). The Global Entrepreneurship Index (GEINDEX). Jena Economic Research Papers(28).

Akın, H. (2020). Türkiye'de iş yapma ortaminin girişimcilik ve ekonomik özgürlükler açısından değerlendirilmesi. Bilig(55), 21-49.

Akıncı, M., Erkal, G., ve Yılmaz, Ö. (2015). Ekonomik özgürlükler ve yosuzluk ilişkisi: Türkiye için bir zaman serisi analizi. EMEK ve TOPLUM, 4(8), 144-165.

Altman, M. (2008). How much economic freedom is necessary for economic growth? theory and evidence. Economics Bulletin, 15(2), 1-20.

Antoncic, B. (2007). Intrapreneurship: A comparative intrapreneurship structural equation modeling. Industrial Management \& Data Systems, 107(3), 309-325.

Audretsch, D. B. (2003). Entrepreneurship a survey of the literature. Brussels, European Communities.

Batjargal, B. (2003). Social capital and entrepreneurial performance in Russia: A longitudinal study. Organization Studies, 24(4), 535-556.

Baumol, W. J. (1990). Entrepreneurship: Productive, unproductive and destructive. Journal of Political Economy(98), 893-920.

Beach, W. W., and Miles, M. A. (2005). Explaining the Factors of the Index of Economic Freedom, Miles, M. A., Feulner, E. J., O'Grady, M. A., Eiras, A. I., and Schevey A. (Ed.), Washington, The Heritage Foundation and Dow Jones.

Beach, W. W., and Kane, T. (2013). Methodology: Measuring the 10 economic freedoms, 2008 index of economic freedom. Washington, The Heritage Foundation.

Bennett, D. L., and Nikolaev , B. (2019). Economic freedom, public policy, and entrepreneurship. Gwartney, R, James L. (Ed.), Economic Freedom of the World: 2019 Edition, Canada, Fraser Institute, 199-224.

Bergmann, H., Mueller, S., and Schrettle, T. (2013). The use of global entrepreneurship monitor data in academic research: A critical inventory and future potentials, Genèva, Inderscience Publishers. 


\section{F. F. Altıntaş 13/2 (2021) 1835-1855}

Bjørnskov, C., and Foss, N. J. (2008). Economic freedom and entrepreneurial activity. Public Choice(134), 307328.

Bosma, N., and Kelley, D. (2019). Global entrepreneurship monitor 2018/2019 report. The Global Entrepreneurship Research Association.

Bosma, N., and Levie, J. (2010). Global entrepreneurship monitor. Global Entrepreneurship Research Association.

Büyükyılmaz, O., ve Fidan, Y. (2017). Algılanan örgütsel desteğin örgütsel vatandaşlık davranışı üzerindeki etkisinde örgütsel güvenin aracllık rolü. Business \& Management Studias: An International Journal, 5(3), 500-524.

Campbell, N. D., and Rogers, T. M. (2007). Economic freedom and net business formation. Cato Journal, 27(1), 23-36.

Caudill, S. B., Zanella , F. C., and Mixon, F. G. (2000). Is economic freedom one dimensional? A factor analysis of some common measures of economic freedom. Journal of Economic Development, 25(1), 17-40.

Dam, M. M., ve Şanlı, O. (2019). Ekonomik özgürlügü̈n büyüme üzerindeki etkisi: BRIC-T ülkeleri üzerine bir panel ARDL analizi, Atatürk Üniversitesi İktisadi ve İdari Bilimler Fakültesi Dergisi, 33(4), 1027-1044.

Demsetz, H. (1982). Barriers to entry. American Economic Review(72), 47-57.

Djankov, S., Ganser, T., McLiesh, C., Ramalho, R. M., and Shleife, A. (2009). The effect of corporate taxes on investment and entrepreneurship. National Bureau of Economic Research, 1-58.

Dollinger, M. J. (2008). Entrepreneurship: Strategies and resources. Lombard, Illinois, Marsh Publication.

Drucker, P. F. (2002). Innovation and entrepreneurship practice and principles. Manhattan, HarperCollins Publischers.

Echeverri, H. H., Haar, J., and Estévez-Bretón, J. B. (2013). Foreign investment, institutional quality, public expenditure and activity of venture capital funds in emerging countries. Medellin, Documentos de Trabajo CIEF 011808.

Elverdi, S., ve Atik, H. (2020). Girişimcilik ve ekonomik büyüme: Avrupa ve Kuzey Amerika ülkeleri üzerine bir uygulama. Uluslararası Sosyal Araştırmalar Dergisi, 13(69), 1170-1179.

Falck, O., and Gäbler, S. (2016). Einfluss der sozialisierung im schulalter auf das unternehmertum. ifo Dresden, 23(4), 29-33.

Faria, H., and Montesinos, H. (2009). Does economic freedom cause prosperity? Public Choice, 141(1), 103-127.

Fornell, C., and Larcker, D. F. (1981). Evaluating structural equation models with unobservable variables and measurement error. Journal and Marketing Research, 18(1), 39-50.

Fraser Institute,. (2017). Economic freedom report. Vancouver, The Fraser Institute.

Freedom House. (2020). Freedom house report. Washington, Freedom House .

Freytag, A., and Thurik, R. (2007). Entrepreneurship and its determinants in a cross-country setting. J. Evol $\operatorname{Econ}(17), 117-131$.

Gerni, M., Emsen, Ö. S., Özdemir, D., and Buzdağll, Ö. (2012). Yolsuzluğun belirleyicileri ve büyüme ile ilişkileri. International Conference On Eurasian Economies, 131-139.

Gilad, B., and Levine, P. (1986). A behavioural model of entrepreneurial supply. Journal of Small Business Management(24), 45-53.

Gül, M., ve Gül, K. (2018). Balıkesir ilinde kadın girişimci profili ve sorunlar: yiyecek sektöründe bir uygulama. Dumlupinar Üniversitesi Sosyal Bilimler Dergisi(56), 82-96.

Gwartney, J. D., Block, W., and Lawson, R. A. (1992). Measuring economic freedom. Easton, S. T., and Walker M. A, (Ed.), Vancouver, Fraser Institute. 


\section{F. F. Altıntaş 13/2 (2021) 1835-1855}

Gwartney, J. D., Lawson, R. A., and Holcombe, R. G. (1999). Economic freedom and the environment for economic growth. Journal of Institutional and Theoretical Economics (JITE) / Zeitschrift für die gesamte Staatswissenschaft, 155(4), 643-663.

Gwartney, J., and Lawson, R. (2003). The concept and measurement of economic freedom. European Journal of Political Economy, 19, 405-430.

Hair, J. F., Black, W. C., Babin, B. J., and Anderson, R. (1998). Multivariate data analysis. Essex, England: Pearson Education.

Hayek, F. A. (1960). The constitution of liberty . Chicago, University of Chicago.

Heritage Fondation. (2020). Economic freedom: Gaining ground around the world . Heritage Fondation.

Holmes, K. R., and Spalding, M. (2011), http://thf_media.s3.amazonaws.com/2011/pdf/UA7.pdf. (Erişim Tarihi: 2 Kasım 2020).

Hossain, M. (2016). Foreign direct investment, economic freedom and economic growth: Evidence from developing countries. International Journal of Economics and Finance, 8(11), 200-214.

Işık, N., Göktaş, D., ve Kılınç, E. C. (2011). İktisadi büyümede girişimciliğin rolü. Girişimcilik ve Kalkınma Dergisi, 6(1), 147-178.

Kantar, K. (2019). Gelişmekte olan ülkelerde ekonomik özgürlüğün yoksulluk üzerine etkisi. Karamanoğlu Mehmetbey Üniversitesi Sosyal Bilimler Enstitüsü, Yayımlanmamış Yüksek Lisans Tezi. Karaman.

Karabıyık, C., ve Çilbant, C. (2017). Girişimciliğin belirleyicileri: Panel veri analizi. Politik, Ekonomik ve Sosyal Araştırmalar Kongresi. Ankara, Pesa.

Karadağ, H. (2018). Girişimcilik politika ve stratejilerinin girişimcilik ekosisteminin gelişimi üzerindeki etkileri:Doğu Asya örneği. Doğu Asya Araştırmaları Dergisi, 1(2), 63-80.

Kaya, A. İ., ve Çalışkan, Z. (2016). Ekonomik özgürlüklerin sağlık ve eğitime etkisi: panel veri analizi. Gazi Üniversitesi İktisadi ve İdari Bilimler Fakültesi Dergisi, 18(1), 81-102.

Kaya, Ş. (2019). Lisans öğrencilerinin grişimcilik eğilimlerinin bilgi teknolojileri yterliliklerine göre değerlendirilmesi: Aydın Adnan Menderes Üniversitesi turizm fakültesi örneği. Adnan Menderes Üniversitesi Sosyal Bilimler Enstitüsü, Yayımlanmamış Yüksek Lisans Tezi. Aydın.

Kešeljevic, A. (2007). Indexes of economic freedom-an outline and open issues. Rad. Ekon. fak. Rij, 25, 223-243.

Kim, M., Kim, H., Lee, S., and Kum, G. (2015). Development of a comprehensive global entrepreneurship index; global entrepreneurship trend report. Korea Entrepreneurship Foundation.

Kirzner, I. M. (1992). The Meaning of Market Process Essays in the Development of Modern Austrian Economics. London, Routledge.

Kutbay, H. (2020). Ekonomik özgürlük ve vergi gelir performansı arasındaki ilişki: Yükselen piyasa ekonomileri için panel veri analizi. Pamukkale Üniversitesi Sosyal Bilimler Enstitüsü Dergisi(40), 303-318.

Lee, D. R. (1991). The seeds of entrepreneurship. The Journal of Private Enterprise(7), 20-35.

McMullen, J. S., Bagby, D., and Palich, L. (2008). Economic freedom and the motivation to engage in entrepreneurial action. Texas, Baylor University.

Meydan, C. H., ve Şeşen, H. (2015). Yapısal Eşitlik Modellemesi AMOS Uygulamaları. Ankara, Detay Yayıncılık.

Miles, M. A., Holmes, K. R., O'Grady, M. A., Ana, I. E., Scheafer, B. D., and Kim, A. B. (2006). 2006 Index of economic freedom, explaining the factors of the index of economic freedom. Washington, The Heritage Foundation and Dow Jones \& Company.

Miller, T., and Kim, A. B. (2013). Defining economic freedom, 2013 index of economic freedom, Miller, K., Holmes, K. R., and Feulner, E. J., (Ed.), Washington, The Heritage Foundation.

Miller, T., Kim , A. B., and Holmes, K. R. (2014). Highlights of the 2014 index of economic freedom promoting economic opportunity and prosperity. Washington, The Heritage Foundation The Wall Sreet Journal. 
Miller, T., Kim, A. B., and Roberts, J. M. (2020). 2020 Index of economic freedom. Washington, The Heritage Foundation.

Nyström, K. (2008). The institutions of economic freedom and entrepreneurship: Evidence from panel data. Public Choice, 136(3), 269-282.

Ovaska, T., and Sobel, R. (2005). Entrepreneurship in post-socialist economies. Journal of Private Enterprise, 21, $8-28$.

Öztürk Çetenak, Ö., ve Işık, M. (2016). Ekonomik özgürlükler ile ekonomik büyüme arasındaki nedensellik ilişkisi: OECD ülkeleri üzerine bir uygulama. Nevşehir Hacı Bektaş Veli Üniversitesi Sosyal Bilimler Enstitüsü Dergisi, 6(1), 1-16.

Pehlivanoğlu, F., ve Kayan, K. (2019). Türkiye'de girişimcilik: Mevcut durum analizi ve çözüm önerileri. Kırklareli Üniversitesi İktisadi ve İdari Bilimler Fakültesi Dergisi, 8(1), 58-78.

Potrafke, N. (2013). Economic freedom and government ideology across the german states. Regional Studies, $47(3), 433-449$.

Prasetyo, E. P. (2019). Role of entrepreneurial culture as the driver of economic growth. International Journal of Economics and Financial Issues, 9(3), 237-243.

Say, J. B. (1971). A treatise on political economy or the production, distribution and consumption of wealth. New York: A.M. Kelley Publishers.

Schumpeter, J. (1934). The theory of economic development: An inquiry into profits, capital, credit, interest, and the business cycle. Harvard Economic Studies, 46.

Sobel, R. S. (2008). Testing baumol: Institutional quality and the productivity of entrepreneurship. Journal of Business Venturing(23), 641-655.

Sobel, R. S., Clark, J. R., and Lee, D. R. (2007). Freedom, Barriers to entry, entrepreneurship,. Rev Austrian Econ(20), 221-236.

Stansel, D. (2012). An economic freedom index for u.s. metropolitan areas. Journal of Regional Analysis and Policy, 43(1), 1-29.

Stenholm, P., Ács, Z. J., and Wuebker, R. (2013). Exploring country-level institutional arrangements on the rate and type of entrepreneurial activity. Journal of Business Venturing, 28(1), 176-193.

Sucu, M. B. (2017). Yükselen piyasa ekonomilerinde ekonomik özgürlük, büyüme ve kalıkınma ilişkisi: Bir panel veri analizi. Bulletin of Economic Theory and Analysis, 2(2), 135-167.

Şahin, D. (2017). Gelişmiş ülkelerde yolsuzluk ve ekonomik özgürlük ilişkisinin analizi. Adnan Menderes Üniversitesi, Sosyal Bilimler Enstitüsü Dergisi, 4(3), 112-121.

Şahin, M. (2016). Bölgesel girişimcilik ekosistemi. Namık Kemal Üniversitesi Sosyal Bilimler Enstitüsü, Yayımlanmamış Yüksek Lisans Tezi. Tekirdağ.

Şahinoğlu, K. T., ve Yakut, S. G. (2019). Yapısal eşitlik modeli ile özgürlüklerin ekonomik performansa etkisi üzerine bir inceleme. Ekoist: Journal of Econometrics and Statistics(30), 1-20.

Şenturan, Ş., ve Şentürk, N. (2016). Girişimciliğin gelişimi ve mikrofinans uygulamalarının önemi. Uluslararası Yönetim İktisat ve İşletme Dergisi(ICAFR 16 Özel Sayıs1), 812-822.

Torun, Y. (2019). Küresel girişimcilik endeksine göre ülkelerin veri madenciliği yöntemlerine göre sınflandırlması. Trakya Üniversitesi Sosyal Bilimler Enstitüsü, Basılmamış Yüksek Lisans Tezi, Edirne.

Ünüvar, O. (2019). Ekonomik büyüme ve kalkınmada girişimciliğin rolü ve önemi. Çağ Üniversitesi Sosyal Bilmler Enstitüsü, Basılmamış Yüksek Lisans Tezi, Mersin.

Valliere, D. (2008). Exploring buddhist influence on the entrepreneurial decision. International Journal of Entrepreneurial Behaviour \& Research, 14(3), 172-191. 
Weber, R., and Powell, B. (2013). Economic freedom and entrepreneurship: A panel study of the United States. The American Journal of Entrepreneurship(6), 67-87.

Wennekers, S., and Thurik, R. (1999). Linking entrepreneurship and economic growth. Small Business Economics, 13(1), 27-55.

Williamson, C. R., and Mathers, R. L. (2009). Economic freedom, culture, and growth. Virginia, George Mason University.

Wong, P. K., Ho, Y. P., and Autio, E. (2005). Entrepreneurship, innovation and economic growth: Evidence from GEM data. Small Business Economics(24), 335-350.

https://www.heritage.org/index/download\# (Erişim Tarihi: 09.10.2020)

https://thegedi.org/wp-content/uploads/2021/02/2019_GEI-2019_final_v2.pdf (Erişim Tarihi: 10.10.2020) 